\title{
TECTONOPHYSICAL RESEARCH AT INSTITUTE OF THE EARTH'S CRUST SB RAS: MAJOR ACHIEVEMENTS AND ACTUAL PROBLEMS
}

\author{
S. I. Sherman, K. Zh. Seminsky \\ Institute of the Earth's Crust SB RAS, 664033, Irkutsk, Lermontov street, 128, Russia
}

Abstract: The article presents major results which have been obtained during 30 years of researches conducted by the Laboratory of Tectonophysics at the Institute of the Earth's Crust.

General regularities in organization of fault-block structures in the brittle lithosphere are established. Relations between main parameters of faults are investigated, and their connection with the lithospheric structure and recent crustal movements is shown. A rheological model of vertical zoning of faults is proposed. Internal structures of faults are studied; stages in faulting are generally defined in terms of time; regularities of patterns of joints inside faults are described; and original methods of mapping such joints are proposed to reveal tectonic conditions of faulting.

Based on seismic monitoring, new methods of quantitative assessment of relative activity rates of faults in real time are developed. Such methods are applied to delineate zones of recent destruction of the lithosphere in the Central Asian region. The state of stresses of the lithosphere is mapped, and the new map allows us to reveal regularities in the spatial mosaic of regions differing by types of stress fields.

Our physical experiments conducted in compliance with similarity conditions are aimed at studying faulting mechanisms with regard to variable loads. A special set of experiments is devoted to the Baikal rift system. Cases of application of tectonophysical methods to study fault tectonics, the state of stresses and seismicity of the lithosphere are described. Prospects of tectonophysical researches conducted in the Laboratory and potentials of integration with studies of other research teams are considered.

Keywords: tectonophysics, fault, area of dynamic impact of fault, fault zone, stress fields, seismicity, lithosphere, similarity conditions.

Recommended by E.V. Sklyarov 16 October 2009

Sherman S.I., Seminsky K.Zh. Tectonophysical research at Institute of the Earth's crust SB RAS: major achievements and actual problems // Geodynamics \& Tectonophysics. 2010. V. 1. № 1. P. 4-23.

\section{ТЕКТОНОФИЗИЧЕСКИЕ ИССЛЕДОВАНИЯ В ИНСТИТУТЕ ЗЕМНОЙ КОРЫ СО РАН: ПРИНЦИПИАЛЬНЫЕ ДОСТИЖЕНИЯ И АКТУАЛЬНЫЕ ЗАДАЧИ}

\section{С. И. Шерман, К. Ж. Семинский}

Институт земной коры СО РАН, 664033, Иркутск, ул. Лермонтова, 128, Россия

Аннотация: Изложены основные результаты исследований сотрудников лаборатории тектонофизики Института земной коры СО РАН за тридцатилетний период. Установлены общие закономерности организации разломноблоковых структур хрупкой литосферы. Изучены соотношения основных параметров разломов, показана их связь со структурой литосферы, современными движениями земной коры. Предложена реологическая модель вертикальной зональности разломов. Детально исследована внутренняя структура разломов, установлены об- 
щие временные этапы ее становления, показаны закономерности организации внутриразломной трещиноватости и методы ее картирования для определения тектонических условий формирования разломов. Предложены методы количественной оценки относительной активности разломов в реальном времени на основе сейсмического мониторинга. На базе их применения выделены зоны современной деструкции литосферы в пределах Центрально-Азиатского региона. Составлена карта напряженного состояния литосферы, и намечены закономерности пространственного расположения на земном шаре регионов с различными типами полей напряжений. Проведены физические эксперименты с соблюдением условий подобия для выяснения механизма формирования разломов при разных условиях нагружения, а также комплекс экспериментов для выяснения механизма формирования Байкальской рифтовой системы в целом. Приведены примеры практического применения комплекса тектонофизических методов при изучении разломной тектоники, напряженного состояния литосферы и её сейсмичности. Рассмотрены перспективы дальнейших тектонофизических исследований.

Ключевые слова: тектонофизика, разлом, область динамического влияния разлома, разломная зона, поля напряжений, сейсмичность, литосфера, условия подобия.

\section{ВведЕНИЕ}

Первые тектонофизические исследования в Институте земной коры СО РАН относятся к началу 60-х годов XX века. Их развитие и обобщение выполнены в монографии С.И. Шермана [1977], в которой рассмотрены тектонофизические закономерности формирования крупных разломов земной коры. Впервые показаны численные взаимоотношения главных параметров разломов - длины и глубины, длины и амплитуды смещения, длины и густоты, а также оценены определяющие их факторы. Предложена модель строения разлома, учитывающая изменения физических свойств земной коры с глубиной (рис. 1) и не потерявшая своей актуальности до настоящего времени. Позже зональное строение разломов вкрест простирания было детализировано в работах С.И. Шермана, С.А. Борнякова и В.Ю. Буддо [1983] и особенно детально в публикациях [Scholz, 2002; и более ранние работы]. Было показано, что разрывообразование в земной коре происходит по законам деформирования и разрушения тела Максвелла. Проанализированы общие закономерности, определяющие густоту сетки разломов, на основе которых разработаны рекомендации по использованию соотношений параметров при геологосъемочных и поисково-разведочных работах [Шерман, 1977].

Развитие этих исследований было продолжено в обобщающих монографиях, объединенных общим названием «Разломообразование в литосфере» [Шерман и др., 1991, 1992, 1994]. Они суммировали результаты целенаправленных полевых и лабораторных экспериментальных работ по изучению физических закономерностей развития разрывов в условиях преобладающих типов напряженного состояния литосферы: сдвига, растяжения и сжатия. Объединяющей нитью через все книги прошла идея использования меры и числа при анализе тектонических процессов и формирования разноранговых разрывов. При исследованиях особое внимание всегда обращалось на структуру разломов, их внутреннее строение и количественную характеристику, соотношения основных параметров как между собой, так и со структурными параметрами литосфе- ры. Физическое и математическое моделирование, как неотъемлемая часть всех выполняемых работ, существенно дополнило геологические наблюдения динамики разрывов и полей деформаций.

Значительные результаты были получены вследствие широкого применения соотношений параметров разломов и дальнейшего развития этого направления при исследовании глубины проникновения разломов [Саньков, 1989], в прикладной геодинамике [Levi, Sherman, 1995], при изучении структурной зональности разломов [Лобацкая, 1987], при тектонофизическом анализе внутренней структуры разломных зон [Семинский, 1990, 2003], исследовании областей динамического влияния разломов [Шерман и др., 1983].

В интегрированной форме следует выделить наиболее значимые проблемы в области тектонофизики, решаемые в Институте земной коры.

\section{ОБЩИЕ ЗАКОНОМЕРНОСТИ ОРГАНИЗАЦИИ РАЗЛОМНО-БЛОКОВЫХ СТРУКТУР ЛИТОСФЕРЫ}

На основании большого количества эмпирических и экспериментальных данных [Шерман, 1977; Шерман и др., 1991, 1992, 1994; Sherman, 1977, 1992] сделан обобщающий вывод о том, что независимо от вида напряженного состояния литосфера в постоянном поле напряжений разрушается по законам упруговязкого тела Максвелла. Общая закономерность деструкции литосферы при формировании разломов описывается уравнением:

$$
L_{p}=A / N_{p}^{d}
$$

где $L_{p}$ - длина разломов, $N_{p}-$ их количество, $A$ и $d-$ эмпирические коэфффициенты, причем $d \approx 0.4$.

Закономерности разрушения прослеживаются в характере формирования крупных разломов, развитие которых реализуется стадийно и дискретно даже в условиях постоянного тектонического режима. Дискретный характер формирования разломов не сказывается на соотношении их параметров. Для всех морфологогенетических разновидностей разломов четко прослеживается нелинейная связь между основными параметрами: длиной и количест- 


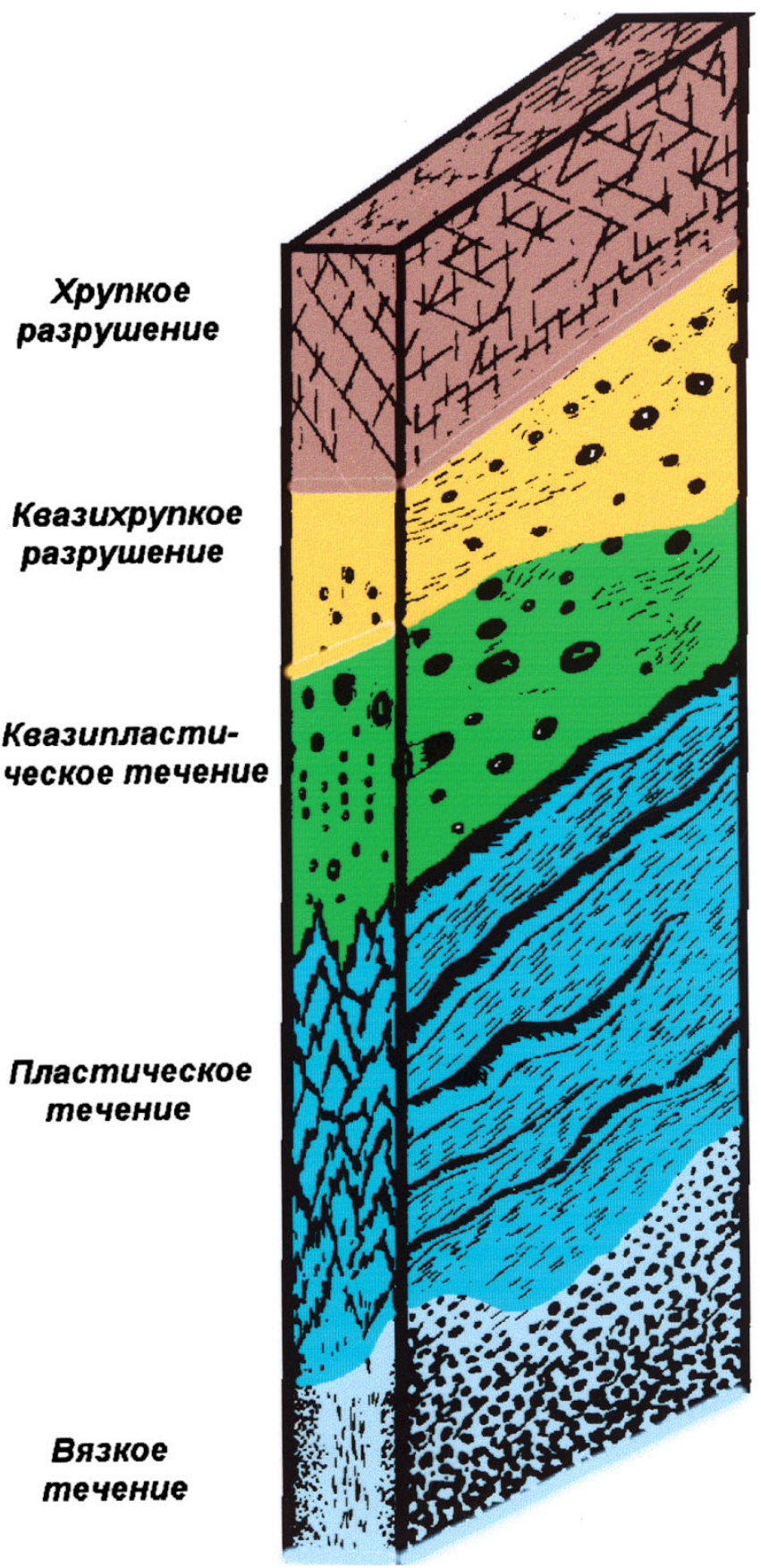

Рис. 1. Вертикальный реологический разрез зоны генерального разлома.

Fig. 1. Vertical profile showing the rheology of the major fault.

вом, длиной и глубиной проникновения, длиной и амплитудой смещения, длиной и расстоянием (шагом) между субпараллельными разломами, а также между амплитудой смещения и шириной зоны дробления. Для всех видов указанных зависимостей установлены эмпирические уравнения регрессии. Существенный вклад в решение проблемы соотношений глубины проникновения разломов с другими параметрами (длиной, расстоянием между разломами), а также влияния на эти соотношения скорости деформации и неоднородностей разреза коры внесла монография В.А. Санькова [1989], до сего- дняшнего дня остающаяся оригинальным и востребованным изданием.

Регулярность в развитии сетки разломов литосфреры находит логическое продолжение в формировании её разломно-блоковой структуры. Как известно, М.А. Садовский и другие [1987] первыми показали дискретное распределение средних разме-

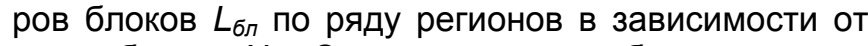

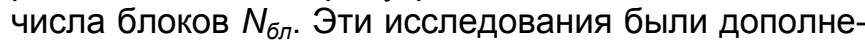
ны наблюдениями в регионах с различными режимами геодинамического развития [Шерман и др., 1999; Шерман и др., 2000б; Sherman et al., 2000]. Результаты математической обработки всех данных указывают на общую закономерность блоковой делимости литосферы, описываемую уравнением:

$$
L_{\text {бл }}=A / N_{\text {бл }}{ }^{c}
$$

при относительно постоянном $c \approx 0.22-0.35$ и вариациях свободного члена $A$ при изменении масштабов выборки. Расчеты показывают, что блоковая делимость литосферы является закономерным выражением ее деструкции. Она развивается упорядоченно, и система блоков образует закономерно изменяющийся иерархический ряд с некоторыми модами преимущественных размеров. Статистическое распределение всей совокупности блоков по размерам закономерно и предсказуемо. Сходство уравнений для блоковой (2) и разломной (1) тектоники литосферы позволяет считать, что в основе деструкции литосферы лежат одни и те же законы, не зависящие от конкретных фрорм ее выражения. Таким образом, деструкция литосферы при разных геодинамических режимах и полях напряжений описывается общим математическим выражением:

$$
L=A / N^{c}
$$

при этом степенной показатель с изменяется от 0.4 до 0.22 при переходе от разломов к блокам.

Выполненные в течение многих лет полевые геолого-структурные наблюдения, их обобщение и теоретический анализ [Шерман и др., 2000б] позволяют аргументировать основной вывод: процесс формирования разломов и разломно-блоковых структур литосферы закономерен для всех иерархических уровней, в своей основе он предсказуем и хорошо корреспондирует с другими геолого-геофизическими явлениями разных масштабных уровней, что подтверждается фризическим и математическим моделированием.

\section{МАТЕМАТИЧЕСКОЕ И ФИЗИЧЕСКОЕ МОДЕЛИРОВАНИЕ И ТЕОРИЯ ПОДОБИЯ}

В настоящее время без этих видов тектонофизических разработок трудно рассчитывать на глубокое изучение закономерностей разломообразования в литосфере. Физическое моделирование требует наличия как минимум трех различных составляющих: специального оборудования, специально подобранных, отвечающих определенным свойствам, композитных материалов и аргументированных критериев 
подобия.

На опытном заводе Иркутского научного центра по заказу Института земной коры была разработана конструкция и изготовлена установка «Разлом» для проведения экспериментов по формированию разрывов в упруговязкой среде при различных режимах нагружения. В качестве модельного материала, близкого по своим свойствам к телу Максвелла, используется глина одного из располагающихся рядом с г. Иркутском карьеров. Её свойства, знание которых чрезвычайно важно для проведения экспериментов и последующей интерпретации опытов, были детально изучены К.Ж. Семинским [1986а]. Эта работа не потеряла своей актуальности и сегодня. Вопросы подобия экспериментов натуральным геологическим условиям фрормирования разломов были разработаны С.И. Шерманом [1984], позднее они были дополнены математической рационализацией применения [Шерман, Бабичев, 1989]. Широкое использование фризического [Борняков, 1990; Шерман и др., 1983; и др.], а впоследствии и математического моделирования [Адамович, 1997] существенно выделяет ведущиеся в ИЗК СО РАН работы, способствует росту их научного авторитета, а также «выживанию» в экономически сложные текущие годы. Этому способствовала серия практически значимых экспериментальных работ [Борняков $и$ др., 2004; Борняков и др., 2000]. Наибольшую значимость имеют две выполненные в разные годы группы экспериментов: изучение областей динамического влияния разломов и моделирование фрормирования структуры Байкальской рифтовой системы (БРС) [Seminskii, Kogut, 2009].

\section{ОБЛАСТИ ДИНАМИЧЕСКОГО ВЛИЯНИЯ КРУПНЫХ РАЗЛОМОВ ЛИТОСФЕРЫ}

Среди характеристик разломов наибольшее значение имеет область их динамического влияния. Под ней понимается окружающее разлом во всех трех измерениях геологическое пространство, в котором проявляются остаточные (пластические или разрывные) и упругие следы деформаций, вызванные формированием разлома или подвижками по нему [Шерман и др., 1983]. В плане это эллипсовидная по форме площадь, на которой изменяется вызванное присутствием дислокаций общее поле напряжений. В зависимости от степени тектонической и динамометаморфической переработки горных пород внутренняя часть области динамического влияния разлома приобретает зональное строение по латерали и на глубину (рис. 2, а, б). Оно не остается постоянным и изменяется при активизации движений по разлому.

Для оценки потенциальных размеров областей динамического влияния разломов в зависимости от их морфологогенетического типа и реологических свойств среды в лаборатории тектонофизики ИЗК СО РАН была проведена большая серия физических экспериментов [Борняков, 1990]. Они позволили установить, что фрормирование зон крупных разломов в литосфере, независимо от морфологогенетического типа, представляет собой процесс сложного структурно-динамического преобразования вмещающей их геологической среды. В нем прослеживаются определенные пространственновременные закономерности: ширина формирующейся зоны разлома (М) в каждый момент времени лимитирована, а её интраструктура развивается стадийно и дискретно-избирательно.

Как показали многочисленные эксперименты, проведенные при варьировании их граничных условий, параметр $M$ имеет многофакторную природу и для каждого морфологогенетического типа разломной зоны может быть оценен через уравнения множественной корреляции:

$$
\begin{aligned}
& M_{1}=a_{1} H+a_{2} \lg \eta+a_{3} \lg V+C_{1}, \\
& M_{2}=a_{4} H+a_{5} A+a_{6} \lg \eta+a_{7} \lg V+C_{2},
\end{aligned}
$$

где $H$ - толщина разрушаемого слоя; $A, V$ - амплитуда и скорость смещения крыльев разломной зоны; $\eta$ - вязкость вмещающей среды; $a_{1,2 \ldots}$ и $C_{1,2}-$ коэфффициенты. Уравнение (4) отражает максимальные размеры $M_{1}$, которые при равенстве всех одноименных параметров у разных морфологогенетических типов разломов будут разными [Шерман и др., 2000б]. Уравнение (5) отражает размеры областей активного структурообразования $M_{2}$ в каждый последующий момент реактивизации подвижек.

Интраструктура воспроизводимых в моделях крупных разломных зон начинает формироваться с заложения в узкой линейно вытянутой области многочисленных изолированных друг от друга мелких разрывов. Их дальнейшие разрастания и взаимодействие идут по ранговому принципу на фоне расширения $M$ [Борняков, 1990; Семинский, 1990]. К моменту достижения параметром М максимального значения разномасштабные разрывные элементы зоны разлома представляют собой характерную кластеризованную систему, исчерпавшую возможности своего развития. Дальнейшее деформационное воздействие на модель приводит к кардинальной структурной перестройке, сопровождающейся заложением и развитием генерации разрывов нового масштабного ранга. Их появление приводит к перераспределению активности между разрывами: одни из них переходят в состояние тектонического покоя, другие, наоборот, становятся более активными. При этом количество активных разрывов и их суммарная длина уменьшаются, а $M_{2}$ становится уже.

Наиболее наглядно стадийность процесса разломообразования отражается в результатах фрактального анализа, который в последние годы активно используется в тектонофизике. Фрактальные размерности могут выступать в роли признака качественного состояния процесса структурно-динамических преобразований в зоне разлома [Sherman, Gladkov, 1999].

Изложенные результаты показывают, что крупные разломные зоны являются сложными структурно-динамическими системами с лимитированными латеральными размерами и с дифференцированнонеоднородной, дискретно развивающейся интраструктурой. Последняя представлена парагенези- 

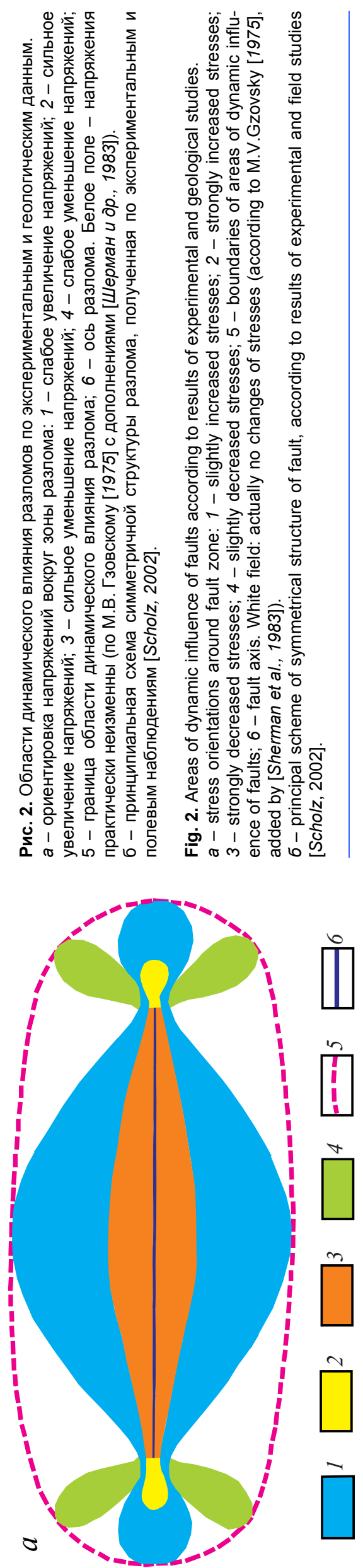

(1) 뭄

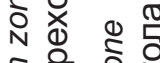

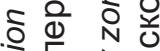

के बत

है



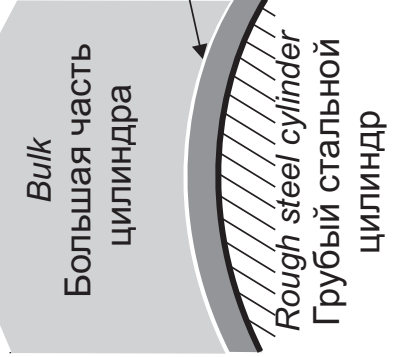

Displacement rate

Скорость смещений

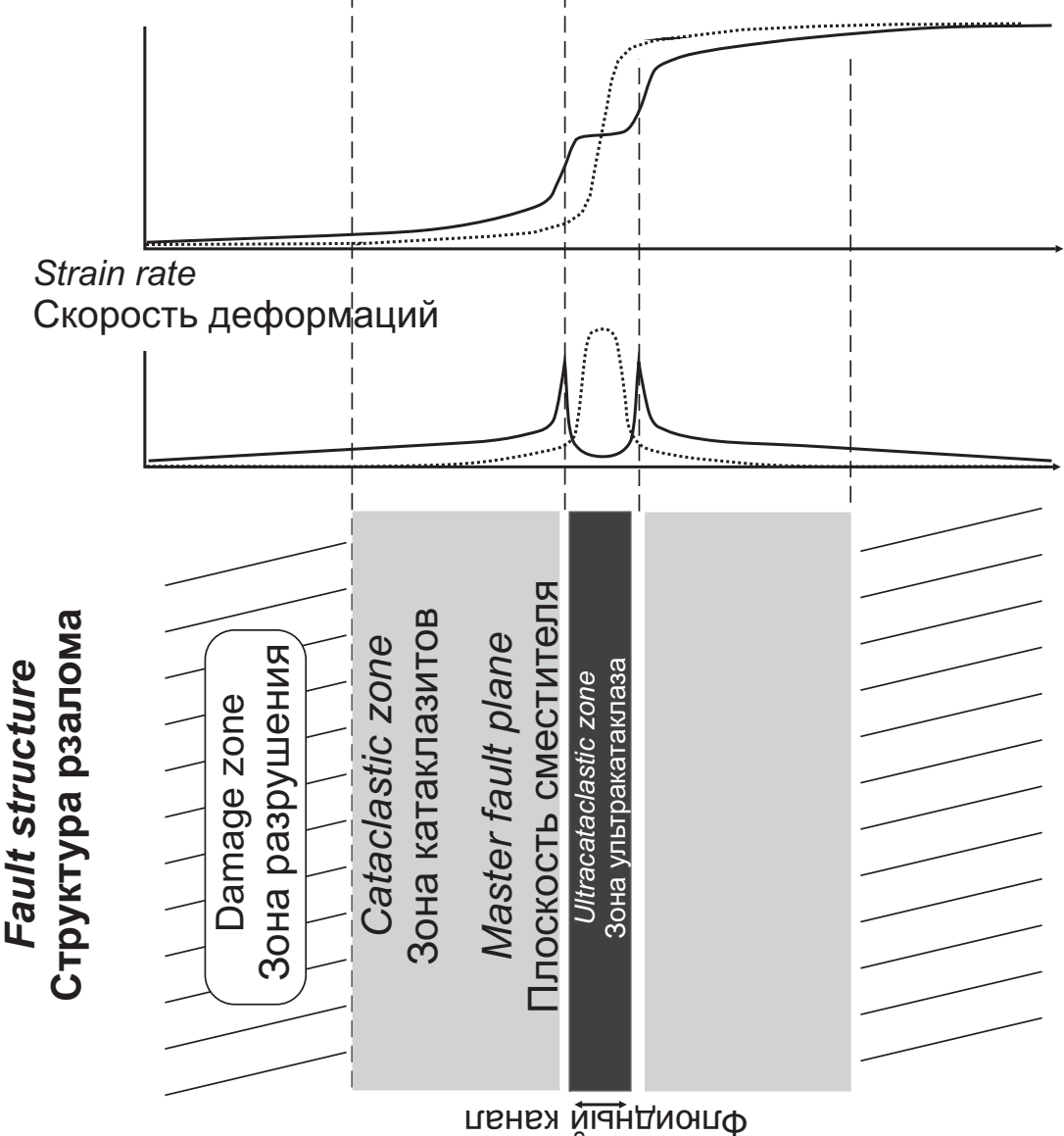

Іәииечо р!пा

винәчgоd

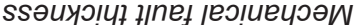

ewoLEed od $\square$ B

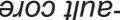

ewoured eHOE

әuOZ łן 
сами разноранговых разломов и блоков. Именно эти первичные структурные элементы разломных зон при благоприятном сочетании различных факторов предопределяют и контролируют процессы рудогенеза и сейсмичности.

Выполненные экспериментальные и полевые наблюдения позволили выделить области динамического влияния разломов, оценить их площадные размеры, наметить принципиальную зональную структуру и установить ее дискретное развитие в пространстве и во времени.

\section{СТРУКТУРНАЯ ЗОНАЛЬНОСТЬ КРУПНЫХ РАЗЛОМОВ}

Области динамического влияния разломов представляют собой значительные пространства. Общие закономерности структурной организации зон динамического влияния крупных разломов с позиций количественного анализа распределения более мелких разрывов детально исследованы Р.М. Лобацкой [1987]. На примерах интраструктур разломов орогенного пояса Внутренней Азии с позиций количественного анализа плотности сопутствующих разрывов установлена принципиальная закономерность зонального строения области динамического влияния. Показано, что основными элементами областей динамического влияния большинства разломов являются дискретные деструктивные поля и объединяющий их магистральный разрыв. Деструктивные поля возникают на самых начальных этапах заложения зоны разлома и длительное время сохраняют стабильным свое положение. Количественные параметры магистральных разломов, сопутствующих разрывов и деструктивных полей описываются статистическими закономерностями, отражающими и характер структурной зональности областей динамического влияния разломов, и специфику разрушения земной коры.

\section{ВНУТРЕННЯЯ СТРУКТУРА КОНТИНЕНТАЛЬНЫХ РАЗЛОМНЫХ $30 \mathrm{H}$}

На базе применения комплекса тектонофизических (полевых и экспериментальных) методов К.Ж. Семинским [2003] было установлено, что основные закономерности формирования внутренней структуры разломных зон сжатия, растяжения и сдвига (т.е. состав парагенезиса разрывов 2-го порядка, характер стадийности, виды неравномерности в нарушенности субстрата) являются едиными, так как определяются видом, кинетикой и способом распространения реализующейся в их пределах прогрессирующей деформации скалывания. На большом фактическом материале убедительно показано [Семинский, 2003], что внутренняя структура разломной зоны любого типа и ранга формируется в течение трех главных дизъюнктивных стадий, каждой из которых соответствуют строго определенные деформационное поведение субстрата, его напряженное состояние, парагенезис разломов 2-го порядка, пространственные и временные вариации параметров разрывной сети (рис. 3). Ранняя дизъюнктивная стадия характеризуется упрочнением деформируемого субстрата и распространением достаточно мелких опережающих нарушений, поздняя дизъюнктивная - ослаблением субстрата с развитием в сравнительно узкой зоне опережающих и трансформационных разрывов, а дизъюнктивная стадия полного разрушения - скольжением блоков по магистральному сместителю, у изгибов которого имеют место активизированные опережающие, трансформационные и собственно оперяющие разрывы. Для каждой из стадий характерна определенная специфика в проявлениях сопутствующих деструкции сейсмической активности, магматизма и рудообразования (рис. 3).

Рациональное сочетание экспериментальных и полевых исследований позволило показать и, главное, теоретически обосновать неравномерность тектонической раздробленности субстрата разломных зон, имеющую место в продольном и поперечном направлениях [Семинский, 1986б, 2003]. Эта неравномерность выражается не только в различной степени нарушенности крыльев дизъюнктива, но и в существовании участков повышенной и пониженной плотности разрывов, чередующихся по простиранию дизъюнктива с определенным шагом, величина которого в ходе структурной эволюции возрастает и к концу поздней дизъюнктивной стадии отражает пространственную неоднородность разрушения 1-го порядка.

Для крупных разломных зон разработан универсальный парагенезис разрывов 2-го порядка, который при учете характера движений и пространственного положения объекта позволяет прогнозировать полные наборы систем, составляющих внутреннюю структуру разломных зон сжатия, растяжения и сдвига в их тектоническом понимании. Парагенезис включает группы опережающих, оперяющих и сопутствующих нарушений. Однако определяющую роль в структуре формирующихся разломных зон играют опережающие разрывы, которые образуют серию частных парагенезисов, в том числе и тройки-системы трещин, имеющие место вблизи разломных поверхностей любого масштабного ранга. Выделение и анализ тройственных парагенезисов трещин, осуществленные для различных по степени тектонической активности регионов, имеют важное значение для геологической практики. Установленный парагенезис трещин лег в основу метода спецкартирования структуры земной коры [Ceминский, 1994, 2005], который позволяет определить местоположение и границы разломных зон, условия их образования, важнейшие особенности внутреннего строения и может быть эффрективно реализован в рамках традиционной геологической съемки любого масштаба [Гладков и др., 2008].

\section{РАЗЛОМНО-БЛОКОВАЯ ТЕКТОНИКА НЕКОТОРЫХ РЕГИОНОВ ЦЕНТРАЛЬНОЙ АЗИИ}

В течение нескольких лет С.И. Шерман и К.Ж. Семинский принимали участие в полевых работах для составления карты разломно-блоковой тектоники территории Вьетнама [Шерман и др., 2000а]. Эти исследования потребовали обобщения материалов 


\begin{tabular}{|c|c|c|c|}
\hline \multirow{2}{*}{$\begin{array}{c}\text { Название } \\
\text { стадии }\end{array}$} & \multicolumn{3}{|c|}{ Характеристика проявлений сопутствующих процессов } \\
\hline & $\begin{array}{c}\text { Схематичный рисунок } \\
\text { (на примере разломной зоны правого сдвига) }\end{array}$ & $\begin{array}{c}\text { Магматизм } \\
\text { и } \\
\text { оруденение }\end{array}$ & $\begin{array}{c}\text { Сейсмическая } \\
\text { активность }\end{array}$ \\
\hline $\begin{array}{c}\text { Ранняя } \\
\text { дизьюнк- } \\
\text { тивная } \\
\text { стадия }\end{array}$ & $\begin{array}{l}/ \text { сдвиги } \\
\text { сбросы } \\
\text { взбросы } \\
\text { прочие разломы }\end{array}$ & $\begin{array}{l}\text { Полосовидный хара- } \\
\text { ктер распределе- } \\
\text { ния интрузивов с } \\
\text { приуроченностью } \\
\text { связанных с ними } \\
\text { рудных полей и мес- } \\
\text { торождений к одной- } \\
\text { двум системам или } \\
\text { Т- и Х-образным } \\
\text { узлам взаимодейст- } \\
\text { вия опережающих } \\
\text { разрывов. }\end{array}$ & $\begin{array}{l}\text { Существование регу- } \\
\text { лярности в простран- } \\
\text { ственном расположении } \\
\text { совокупностей земле- } \\
\text { трясений на фоне об-- } \\
\text { щего рассеянного ха- } \\
\text { рактера распределения } \\
\text { сейсмичности по срав- } \\
\text { нению с последующими } \\
\text { стадиями развития } \\
\text { разломной зоны. }\end{array}$ \\
\hline $\begin{array}{c}\text { Поздняя } \\
\text { дизьюнк- } \\
\text { тивная } \\
\text { стадия }\end{array}$ & $\begin{array}{l}\text { сдвиги } \\
\text { сбросы } \\
\text { взбросы } \\
\text { / прочие разломы }\end{array}$ & $\begin{array}{l}\text { Цепочечно-узловой } \\
\text { характер распреде- } \\
\text { ления интрузивов с } \\
\text { приуроченностью } \\
\text { связанных с ними } \\
\text { рудных полей и ме- } \\
\text { сторождений к спря- } \\
\text { мленным сегмен- } \\
\text { там сместителя и } \\
\text { оперяющим его на- } \\
\text { рушениям, а на уча- } \\
\text { стках сложного стро- } \\
\text { ения - к сочленяю- } \\
\text { щимся (и разветвля- } \\
\text { ющимся) опережаю- } \\
\text { щим разрывам или } \\
\text { располагающимся } \\
\text { между ними блокам. }\end{array}$ & $\begin{array}{l}\text { Ярко выраженная диф- } \\
\text { ференциация разломной } \\
\text { зоны на равноудаленные } \\
\text { друг от друга участки } \\
\text { с практически полным } \\
\text { отсутствием сейсми- } \\
\text { ческих событий в связи } \\
\text { с криповым характером } \\
\text { движений по единичному } \\
\text { разрыву и хорошо лока- } \\
\text { лизованные области с } \\
\text { интенсивным проявлени- } \\
\text { ем сейсмичности в свя-- } \\
\text { зи с разрывообразованием } \\
\text { в их пределах, которое } \\
\text { наиболее развито на дис- } \\
\text { тальных окончаниях этих } \\
\text { областей. }\end{array}$ \\
\hline $\begin{array}{c}\text { Дизьюнк- } \\
\text { тивная } \\
\text { стадия } \\
\text { полного } \\
\text { разруше- } \\
\text { ния }\end{array}$ & $\begin{array}{ll}\text { сдвиги } \\
y \text { сбросы } \\
\text { взбросы } \\
\text { прочие разломы }\end{array}$ & $\begin{array}{l}\text { Цепочечный харак- } \\
\text { тер распределения } \\
\text { интрузивов с приу- } \\
\text { роченностью свя- } \\
\text { занных с ними руд- } \\
\text { ных полей и мес- } \\
\text { торождений к } \\
\text { спрямленным сег- } \\
\text { ментам или изги- } \\
\text { бам магистраль- } \\
\text { ного сместителя, } \\
\text { а также оперяю- } \\
\text { щим его разрывам. }\end{array}$ & $\begin{array}{l}\text { Явная приуроченность } \\
\text { землетрясений к участкам } \\
\text { изгибов магистрального } \\
\text { сместителя, которые с } \\
\text { течением времени исче- } \\
\text { зают в связи с выравни- } \\
\text { ванием его плоскости, } \\
\text { по которой происходят } \\
\text { лишь криповые переме- } \\
\text { щения. }\end{array}$ \\
\hline
\end{tabular}

Рис. 3. Обобщенные схемы внутренней структуры и характеристика сопутствующих деструкции процессов для разломных зон, находящихся на трех разных стадиях развития.

Fig. 3. Generalized schemes of internal patterns and characteristics of processes accompanying destruction for fault zones in three different development stages.

по разломной тектонике Азии, изучения внутренней структуры межблоковых разломов и областей их динамического влияния. В результате анализа тектонических схем и карт разного масштаба составлена карта разломно-блоковой тектоники террито- рии Южной и Юго-Восточной Азии, на которой выделены геологические блоки, контактирующие друг с другом по крупным деструктивным зонам литосферы, являющимся структурным выражением областей динамического влияния межблоковых раз- 
ломов. В пределах каждой из зон среди множества сопутствующих разрывных нарушений отчетливо выделяется главный сместитель (обычно это известные разломы региона - Тань-Лу, Айлао-Шан, Алтынтаг, Главный разлом Гималаев и др.) [Семинский, 2001]. Определяющей особенностью внутреннего строения межблоковых «пространств» является дискретность проявлений в их пределах геологических и геофизических полей. Она выражается в присутствии внутри формирующейся в едином геодинамическом режиме деструктивной зоны отдельных участков, существенно отличающихся типом напряженно-деформированного состояния. Неравномерность внутреннего строения деструктивных зон литосферы отражается в существовании участков, значительно отличающихся по степени деструкции, что находит отражение в полях распределений плотностей эпицентров землетрясений и активных разломов.

Таким образом, для данной территории впервые составлена карта, в которой связаны воедино представления о блоковой делимости литосферы и зонах деструкции как трехмерных геологических телах. Последние в данном случае представляют собой линейно вытянутые участки повышенной распространенности активных разломов и генетически связанных с ними землетрясений. Они охватывают территории, более широкие, чем межплитные границы, т.е. частично распространяются и на внутриплитные пространства. Области динамического влияния крупных межплитных границ, структурно выраженные интенсивной деструкцией литосферы, можно рассматривать как тектонические области, формирование которых отражает одну из стадий структурного развития литосферных плит - основного понятия и образа плитной тектоники.

\section{НАПРЯЖЕННОЕ СОСТОЯНИЕ ЛИТОСФЕРЫ}

Расширение знаний о закономерностях развития разломов в литосфере взаимосвязано с анализом её напряженного состояния. Оно является своеобразной характеристикой тонуса литосфреры, который определяет ее реакцию на различные воздействия и влияет на характер эволюции многих геолого-геофизических процессов. Геолого-структурные и тектонофизические методы играют существенную роль в оценке напряженного состояния литосферы. В Институте земной коры СО РАН составлена первая карта напряженного состояния Байкальской рисртовой зоны [Шерман, Днепровский, 1989a; Sherman, 1992] и осуществлены методические разработки для исследования напряженного состояния земной коры геолого-структурными методами [Шерман, Днепровский, 1989б. Впоследствии эти работы были расширены и составлена новая карта напряженного состояния верхней части литосферы Земли (рис. 4) [Шерман, Лунина, 2001]. При работе над картой был использован новый способ районирования верхней упругой части литосферы по типам напряженного состояния. Интегрированный анализ всех фактических данных позволил выделить в упругой литосфере Земли шесть превали- рующих типов напряженного состояния литосферы, четыре из которых главные: нейтральное, растяжение, сжатие, сдвиг и два промежуточных: растяжение со сдвигом и сжатие со сдвигом. Установлены определенные закономерности в расположении главных типов полей напряжений на поверхности Земли. Одни из них связаны с распределением областей напряжений по отношению к оси вращения планеты и могут характеризоваться использованием сетки географических координат; другие - со структурой верхней части литосферы и ее делением на континентальную и океаническую. Карта заполнила пробелы в фундаментальных представлениях о типах напряженного состояния литосферы, их распространении на поверхности Земли и открыла возможности комплексного использования напряженного состояния литосферы для геодинамических построений и долгосрочных геолого-геофизических прогнозов.

Дополнительные представления об эволюции напряженного состояния земной коры Байкальской рифтовой системы и всей Монголо-Сибирской подвижной области были получены в результате анализа тектонической трещиноватости, штрихов скольжения и смещений по разломам с применением кинематических методов реконструкции полей напряжений [San'kov et al., 1997; Парфеевец, Саньков, 2006; Саньков и др., 1991, 2004]. Неотектонические структуры Северной Монголии и Тувы развивались в условиях режимов сжатия и транспрессии при сжатии в север-северо-восточном направлении.

\section{ФИЗИЧЕСКОЕ МОДЕЛИРОВАНИЕ ФОРМИРОВАНИЯ БАЙКАЛЬСКОЙ РИФТОВОЙ СИСТЕМЫ}

Впервые экспериментальное воспроизведение процесса формирования БРС как целостной структуры выполнено И.В. Лучицким и П.М. Бондаренко [1967]. Концептуальной основой моделирования было господствовавшее в те годы представление о развитии рифтовых впадин на вершинах сводов. Эта ситуация и была промоделирована. Однако при сводообразовании на модели не образовалась характерная для фолангов БРC S-образная форма их соединения с центральной частью. В заключительную стадию эксперимента модель подвергалась дополнительному вращению, позволяющему частично достичь желаемого эфрфекта.

Эти исследования, а также новые представления о комплексном развитии рифтогенеза в Прибайкалье как результате пассивного и активного воздействия Евроазиатской коллизии и подлитосферных конвекционных течений [Логачев и др., 2000] дали основание для новой серии тектонофизических экспериментов [Seminskii, Kogut, 2009] по формированию БРС как целостной структуры. В этих опытах однослойная модель из упруго-пластичной глинистой пасты накладывалась на два штампа, один из которых смещался по типу простого сдвига в горизонтальном направлении и на контакте со вторым штампом имел изгиб, аналогичный по форме прибайкальскому отрезку краевого шва Сибирской 


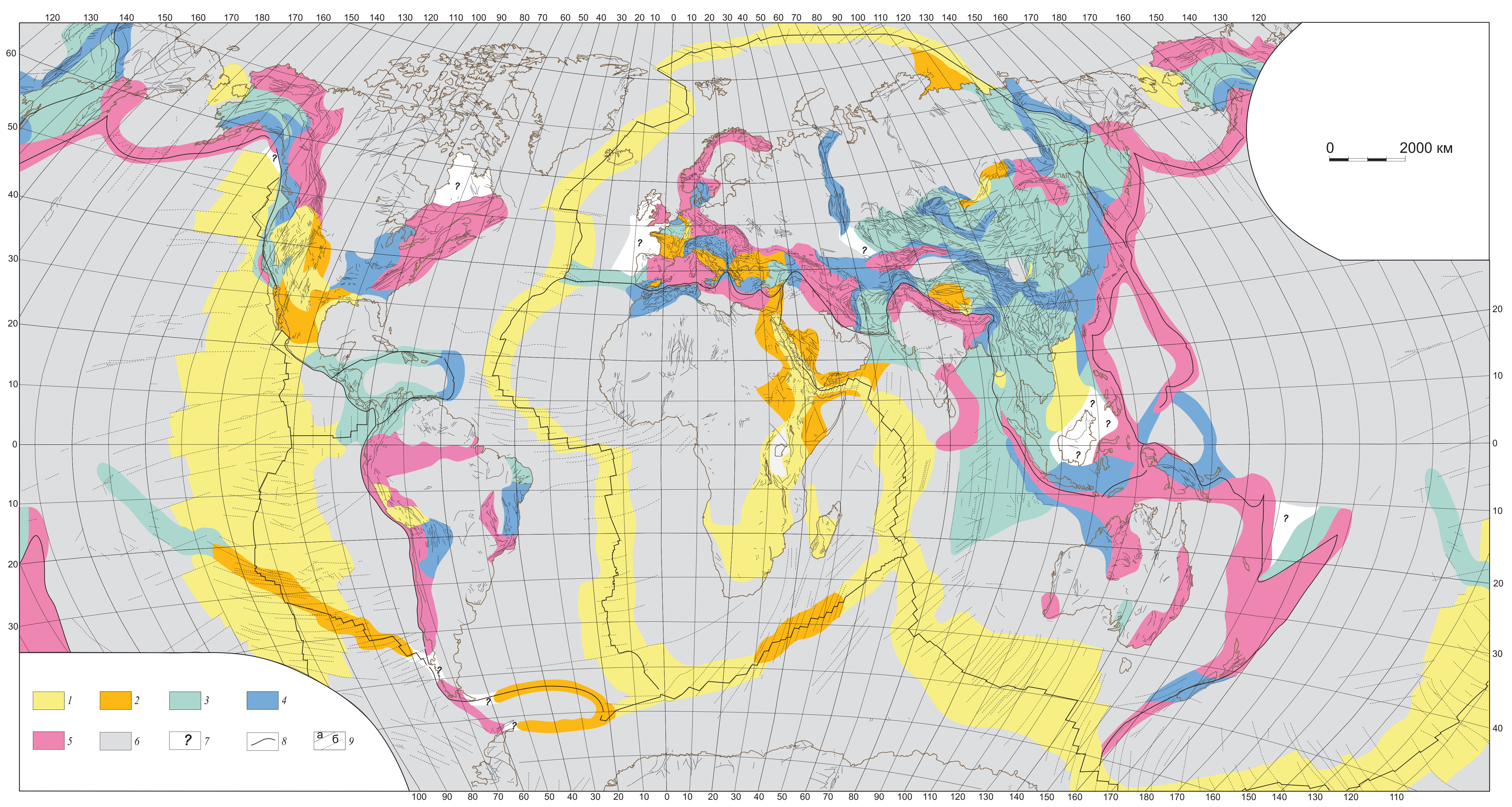

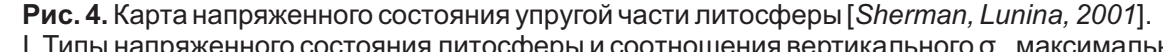

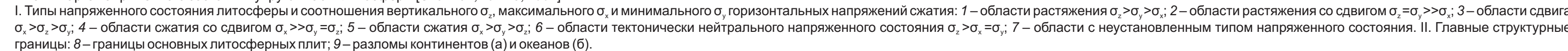

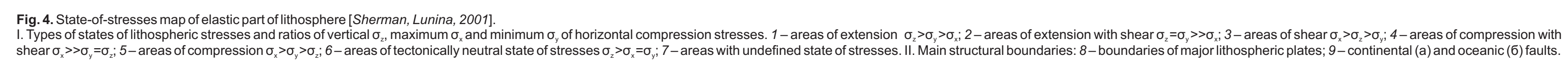


платформы. Данная схема приложения нагрузки в значительной мере соответствует пассивному механизму рифтогенеза, так как разрушение деформируемого слоя происходит вследствие сдвиговых перемещений блоков и развития в модели структуры пулл-апарт без подъема и температурного воздействия, обусловленных в природе влиянием мантийного астенолита.

Моделирование показало, что в экспериментах отчетливо воспроизводятся выделенные ранее главные пространственно-временные закономерности развития БРС, причем в отдельных опытах впервые была достигнута высокая степень подобия морфологии и взаимного расположения ее главных впадин (рис. 5). Это позволило считать, что упругопластическая реакция субстрата с закономерной локализацией деформации, левосдвиговые перемещения блоков и наличие изогнутой в плане инициирующей структурной неоднородности являются определяющими факторами развития БРС. Таким образом, результаты тектонофизического анализа подтверждают и углубляют представления, согласно которым Байкальский рифт зародился в пределах S-образного фррагмента левосдвиговой зоны, где в условиях растяжения происходило разрушение литосферы, которое лишь на заключительной стадии (последние 3.5 млн лет) ускорилось воздействием аномальной мантии. При этом Индо-Евразийская коллизия вследствие относительной молодости не может рассматриваться в качестве причины возникновения блоковых перемещений, так как геологические данные об активизации тектонических процессов у края Сибирского кратона в позднем мезозое подтвердились результатами моделирования, свидетельствующими о длительной эволюции структуры сдвиговой зоны до возникновения растяжения в ее центральной части.

\section{РАЗЛОМНАЯ ТЕКТОНИКА ВО ВЗАИМОСВЯЗИ С НЕОТЕКТОНИЧЕСКИМИ ДВИЖЕНИЯМИ В СЕЙСМОАКТИВНЫХ ЗОНАХ ЛИТОСФЕРЫ}

Хорошо известное положение о том, что развитие разломных зон сопровождается сейсмичностью и сопряжено с деформациями коры и литосферы, а сами деформации находят отражения в неотектонических движениях, существенно дополнено и развито К.Г. Леви на основе тектонофизического анализа [Леви, 1991; Levi, Sherman, 1995; и др.]. В основу исследования положены методы математической статистики и многомерного анализа, позволившие установить зависимости между характеристиками вертикальной и горизонтальной компонент движений литосферы и параметрами геолого-геофизических полей. Удалось выяснить ряд общих закономерностей во взаимоотношениях неотектонических движений с геофизическими полями и течением эндо- и экзогенных процессов. Установлено, что закономерности эволюции внутренней структуры литосферы связаны с термальной эволюцией мантии и находят отражение в неотектонических движениях, разломообразовании, блоковой делимости литосферы и в интенсивности её расслоенности.
Процессы деформации коры и литосферы, разломообразования и изменения в связи с этим реологических свойств литосферы приводят к возникновению сейсмичности. Однако до сего времени, за малым исключением в области разломной тектоники, не всегда удается найти четкие и однозначные зависимости между характеристиками тектонических структур и сейсмичностью. По мнению К.Г. Леви [1991], существующие трудности связаны с тем, что параметры сейсмичности в первую очередь отражают сейсмичность как процесс, а тектонические параметры чаще всего отображают геометрию структур. В связи с этим было предложено представить сейсмичность в виде сейсмоактивных структур, а затем установить связи между сейсмоактивными и тектоническими структурами [Леви, 1991]. Эти связи были подтверждены на примерах изучения разломной тектоники и сейсмичности района Северо-Муйского тоннеля [Саньков и др., 1991]. Выполненный К.Г. Леви тектонофизический анализ неотектонических движений позволил установить общие закономерности вертикальных и горизонтальных неотектонических движений в количественной взаимосвязи, связь движений с толщиной литосферы, корреляцию последней с плотностью разломов, а также ввести в тектонофизику представления о сейсмических структурах [Леви, 1991].

Формирующийся в Институте земной коры СО РАН комплекс представлений об эволюции разломообразования при растяжении литосферы и синхронно протекающей сейсмичности способствовал развитию новой ветви исследований - изучению зон современной деструкции литосферы и ее сейсмичности в интервалах реального времени (десятилетия, годы, месяцы).

\section{ЗОНЫ СОВРЕМЕННОЙ ДЕСТРУКЦИИ ЛИТОСФЕРЫ И ИХ СЕЙСМИЧНОСТЬ}

Параллельно с углубленным и разносторонним изучением внутренней структуры разломных зон были выделены регионы Земли с наиболее интенсивными проявлениями тектонических процессов. Анализ их геолого-геофизических параметров дал основание для введения понятия и выделения зон современной деструкции литосфреры, под которыми понимаются области повышенной раздробленности литосферы, интенсивного напряженного состояния, высоких скоростей деформирования среды, контрастных вариаций параметров геофизических полей и сейсмичности [Шерман, 1996].

Количественные параметры деструкции литосореры и сейсмичности детально изучены на примере Байкальской рифтовой системы и ряда других крупных разломных формирований. С этой целью проведен статистический анализ эпицентрального поля землетрясений БРС за 40-летний период. Установлены и оконтурены ареалы площадей долговременной концентрации эпицентров, на базе которых выделена зона современной деструкции литосферы как единая сейсмоактивная тектоническая структура [Шерман и др., 2004; Sherman et al., 2004]. Выявлены закономерности распределения сильных 

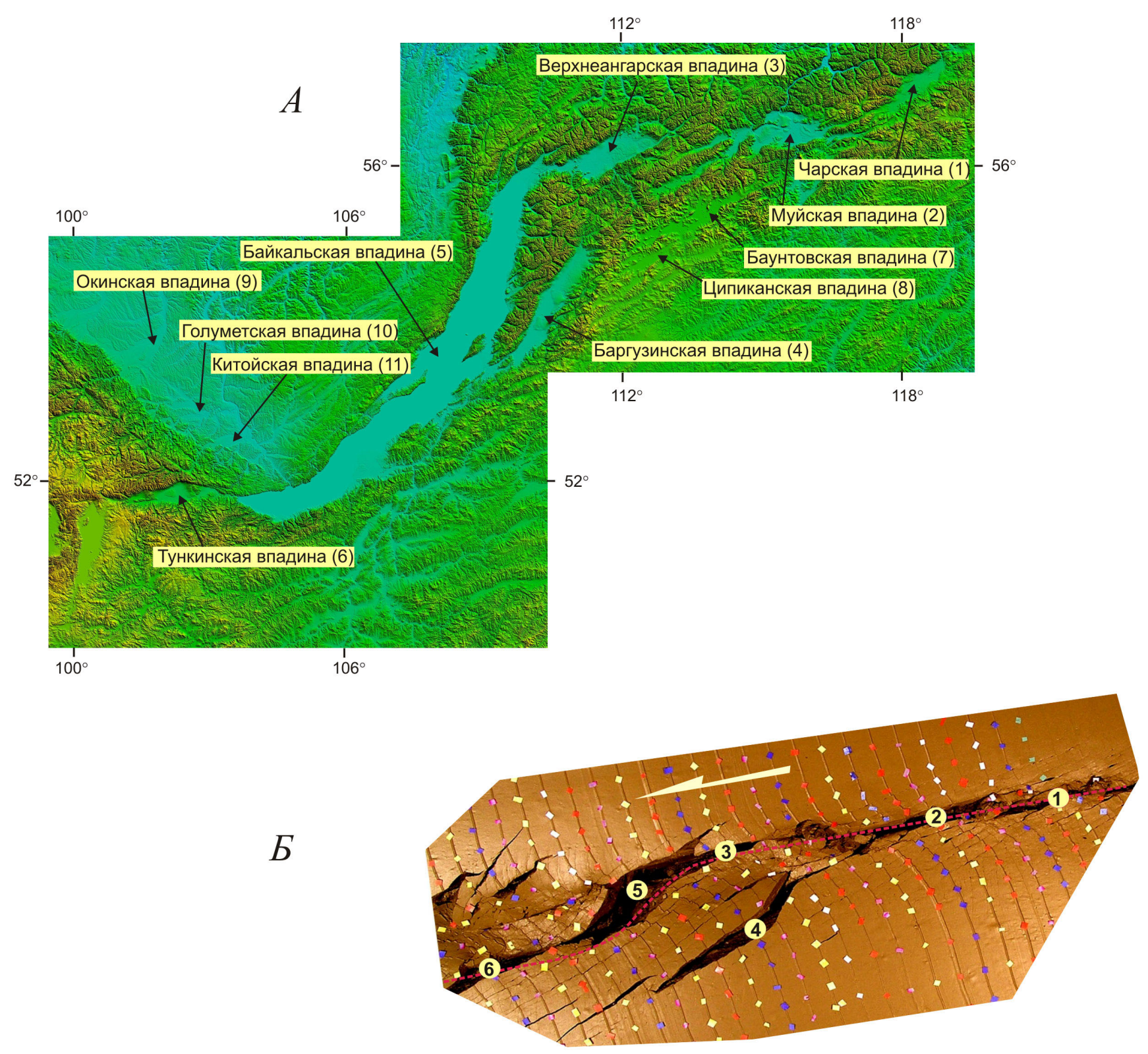

Рис. 5. Разломы и впадины Байкальской рифтовой системы на цифровой модели рельефа $(A)$ в сравнении с аналогичными структурами, воспроизведенными в упруго-пластичной модели при сдвиге вдоль инициирующей неоднородности, осложненной изгибом (Б). Разрывы растяжения (Б) пронумерованы в соответствии с индексацией их природных аналогов (A). Пунктир - примерное положение края подвижного штампа экспериментальной установки на момент фотосъемки; односторонняя стрелка - направление его перемещения.

Fig. 5. Faults and basins of the Baikal rift system in the digital relief model $(A)$ compared with similar structures in the visco-elastic model simulating strike-slip along the initial inhomogeneity complicated by bending $(\overline{)})$.

Extension faults $(\bar{b})$ are numbered according to indexes assigned to corresponding natural faults $(A)$. The dotted line shows approximate positioning of the mobile unit of the experimental installation at the moment when the photo was taken; an arrow shows direction of movement of the mobile unit.

землетрясений по отношению к оси зоны современной деструкции литосферы (рис. 6), а также сильных и слабых событий по отношению к ее фрагментам. Установлены пространственно-временные продольно-поперечные осцилляции очагов землетрясений в пределах областей динамического влияния деструктивной зоны или ее фрагментов. Дискретность и миграция сейсмических событий и их ранговая приуроченность к активным разрывным структурам различных иерархических уровней отражают общие закономерности деструкции литосферы при рифтовом режиме ее развития. Оценивать взаимосвязи между разломной тектоникой и сейсмичностью надо на сопоставимых уровнях деструкции литосферы: редкие сильные события отражают этапы развития всей деструктивной зоны, слабые - ее отдельных составляющих. Отсюда, прогноз сильных сейсмических событий в БРЗ может быть сделан на базе выяснения закономерностей временной миграции сильных событий в зонах конкретных активных 


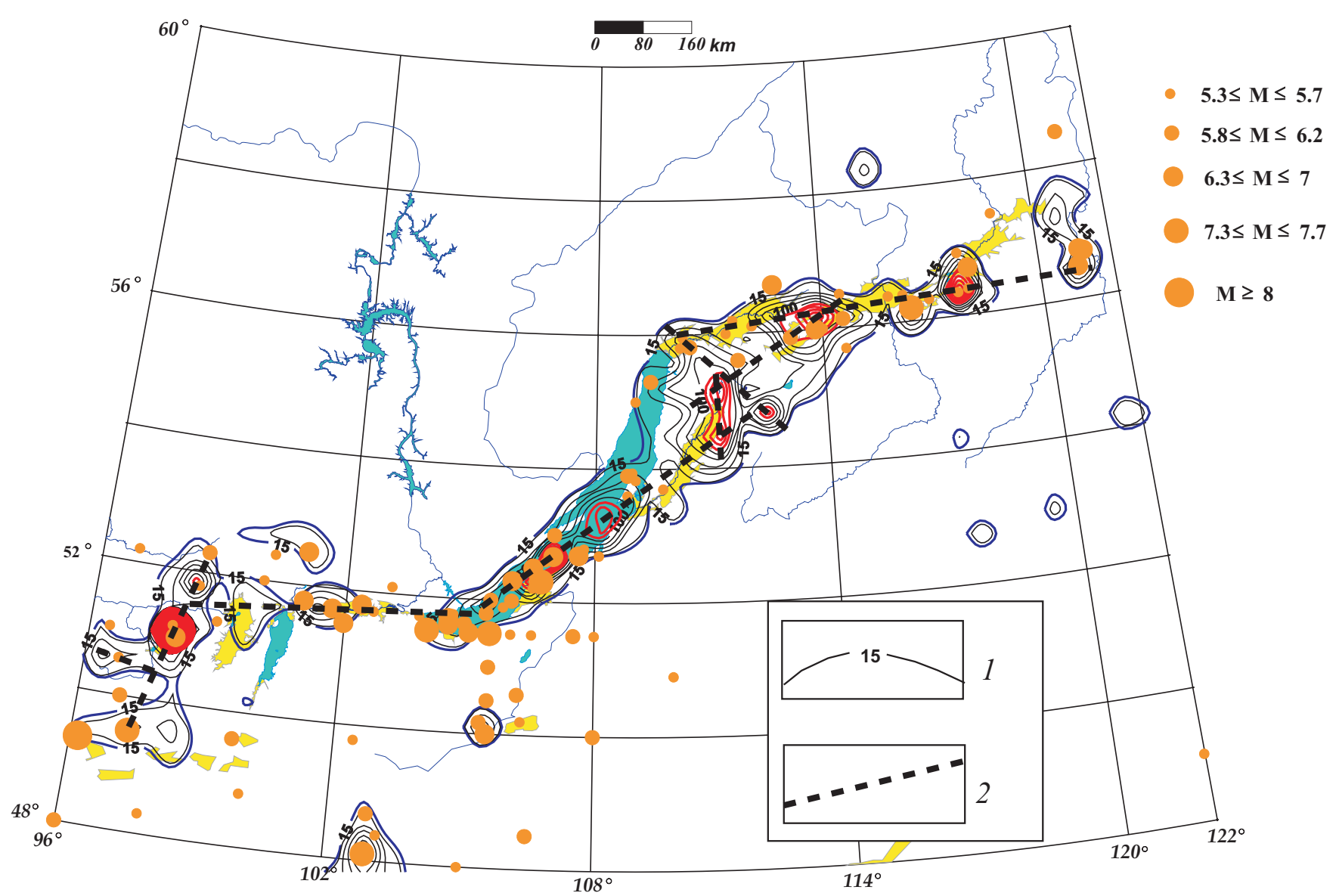

Рис. 6. Зона современной деструкции литосферы с эпицентрами сильных землетрясений: 1 - изолинии плотности эпицентров с шагом 20 событий (первая изолиния 15 соответствует фону; утолщенные изолинии соответствуют ареалам, у которых повышенная плотность эпицентров превышает фоновое значение $\left.+2 \sigma_{\mathrm{D}}\right) ; 2$ - ось деструктивной зоны литосферы.

Справа от рисунка - очаги землетрясений соответствующих магнитуд (1760-1999 гг.).

Fig. 6. Zone of recent deformation of the lithosphere and epicenters of strong earthquakes. 1 - isolines show epicentre densities with level distance of 20 events (isoline 15 shows background; thick isolines show areas with increased density of epicentres that is above the background rate of $+2 \sigma_{\mathrm{D}}$ ); 2 - axis of lithospheric destruction zone.

Right-side insert: Earthquake foci of corresponding magnitudes (1760-1999).

разломов.

\section{НОВЫЕ МЕТОДЫ ОЦЕНКИ АКТИВИЗАЦИИ РАЗЛОМОВ В РЕАЛЬНОМ ВРЕМЕНИ}

Результаты исследований современной геодинамики литосферы позволили выделить группы активных разломов, интенсивность активизаций которых изменяется в интервалах короткого реального времени и практически не зависит от функционирующих геодинамических режимов регионов. Установлено, что разломы активизируются с изменяющейся интенсивностью и чаще, чем фриксируются изменения в тектоническом режиме и региональном поле напряжений. Вывод получен благодаря введению новых параметров численных оценок количественной и энергетической (магнитудной) характеристик разломов. Для оценки интенсивности активизации разломов в реальном времени (месяцы, годы) предложено использовать количественный индекс их сейсмической активности (КИСА) $\xi_{n}\left(\kappa^{-1}\right)$, под которым понимается число сейсмических событий n определенных энергетических классов $K$, приходящихся на единицу длины разлома $L$ (км) при принятой ширине области его динамического влияния $M$ (км) за заданный промежуток времени $t$ (годы) [Шерман и др., 2005]:

$$
\xi_{n}=\sum n(M, K, t) / L \text {. }
$$

Ширина области динамического влияния разлома $М$ определяется по уравнению

$$
M=b L
$$

где $L$ - длина разломов, км; $b$ - коэффрициент пропорциональности, зависящий от $L$ и по эмпирическим данным изменяющийся от 0.03 до 0.09 соответственно для трансрегиональных и локальных разломов [Шерман и др., 1983]. В реальном масштабе времени именно КИСА характеризует нестабильность крыльев разломов и даёт основание для анализа доли участия разнорангового разломного 


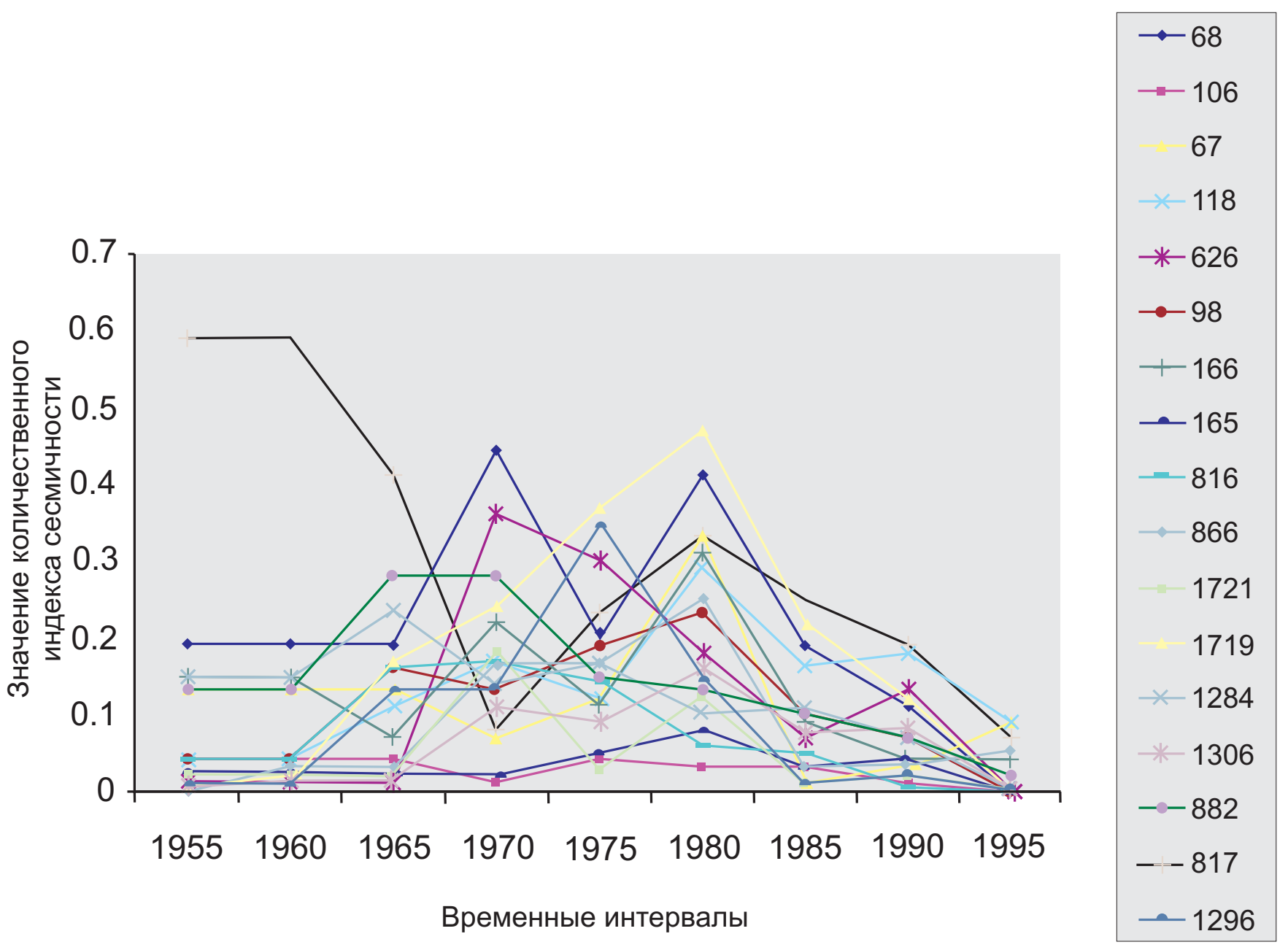

Рис. 7. Вариации количественного индекса сейсмической активности разломов в Байкальской рифтовой системе во времени. Справа в цветовой гамме даны номера разломов по каталогу базы данных.

Fig. 7. Temporal variations of quantitative indexes of seismic activity of faults in the Baikal rift system. At the right, numbers of faults are given according to the database catalogue.

сообщества в сейсмическом процессе.

Для определения энергетического потенциала разломов предложено применять магнитудный (энергетический) индекс сейсмической активности (МИСА) разломов $\xi_{k}$, под которым понимается значение класса максимального сейсмического события $K_{\max }(K=\lg E$, Дж), приходящегося на длину разлома $L$ (км) при принятой ширине области его динамического влияния $M$ (км). МИСА оценивается по выражению:

$$
\xi_{k}=K_{\max (t)}(M, K, t)
$$

где $K_{\max (t)}$ - максимальный класс землетрясения (или его максимальная магнитуда) в области динамического влияния разлома $M$ за заданный промежуток времени $t$ [Шерман, Савитский, 2006].

Вариации КИСА и МИСА на примерах разломной тектоники Центральной Азии свидетельствуют об отсутствии ясно выраженной пространственной закономерности в активизации территориально сближенных ансамблей разломов в чрезвычайно корот- кие интервалы реального времени. Создается впечатление, что активизация разломов в границах сейсмоактивных зон происходит хаотично (рис. 7). Эндогенные источники развития разломов и генетически связанной с ними сейсмичности в задаваемые, с геологической точки зрения мгновенные, интервалы времени остаются пространственно и энергетически стабильными. Следовательно, пространственно-временные закономерности в возбуждении активизации разломов необходимо искать в энергетически слабых, но достаточных для нарушения метастабильного состояния разломно-блоковой среды литосферы триггерных механизмах.

\section{ПРОСТРАНСТВЕННО-ВРЕМЕННАЯ МИГРАЦИЯ ОЧАГОВ В РЕАЛЬНОМ ВРЕМЕНИ (МЕСЯЦЫ, ГОДЫ)}

Ее вариации не могут быть объяснены изменениями напряженно-деформированного состояния среды эндогенной природы. Под этим углом зрения по разработанной методике изучены пространственно-временные закономерности современной ак- 
тивизации разломов, ее источники и механизмы реализации.

В основе разрабатываемых построений лежит представление о том, что землетрясение любого класса, как единичный акт проявления сейсмической активности в зоне динамического влияния разлома, фриксирует нарушение равновесия в его внутренней структуре, сопровождающееся увеличением интенсивности трещиноватости и, при сильных событиях, смещением крыльев. Частота сейсмических событий в зоне разлома отражает интенсивность нарушений динамического равновесия, их вероятную периодичность, а тенденция в пространственной направленности очагов вдоль оси разлома во времени воспроизводит макроскопические изменения зоны разлома и направленность его прорастания в соответствующем направлении. По представлениям С.В. Гольдина [2002], происходит реализация второго механизма развития крупной трещины (разлома - С.Ш., К.С.): её продолжающееся формирование идет по уже существующей перколяционной сети более мелких трещин, и скорость развития (активизации) трещины может быть исключительно низкой, сопоставимой с геологическим временем.

Была детально изучена Байкальская рифтовая система, и для ее активных в интервалах реального времени разломов построены графики, на оси абсцисс которых откладывались длины разломов с соответствующими положениями эпицентров землетрясений; на оси ординат - время событий (рис. 8) [Sherman, Gorbunova, 2008]. На графиках в координатах время-пространство наклоны линий отражают временньіе тренды сейсмических событий на анализируемых разрывах - суть направления их дополнительного «вспарывания», выраженного сейсмическими очагами - эпизодами в долговременном развитии разломов. Эпицентры землетрясений конкретных разломов на сводном графике образуют системы параллельных прямых, как если бы вдоль соответствующих разломов распространялись с постоянной скоростью серии возмущений, инициирующих сейсмические события. Каждая прямая соответствует возмущениям в конкретных разломах, наклон прямых определяет скорость, а их отклонение влево или вправо от вертикали - направление возмущений по простиранию разрывов - активных периодов в их (разломов) развитии. Группирование разломов по критерию одинаковых скоростей - экстремальных возмущений (активизаций) разломов свидетельствует об идентичных параметрах их активизации (рис. 9). По вычисленным скоростным характеристикам и векторам движений деформационных волн возмущения первых четырех групп проведена новая классификация разрывов, проанализировано их пространственное положение в Байкальской рифтовой системе и взаимоотношения некоторых параметров (рис. 10).

В первой группе превалирует вектор активизации с запада на восток в восточной части площади и с востока на запад - в западной; в четвертой все наоборот. Особо выделяются южные части территории, находящиеся в других геодинамических обстановках. По описываемым признакам превали- рования векторов вторую и третью группы можно рассматривать как переходные между первой и четвертой. Совершенно бесспорно для всех четырех групп намечается граница изменений векторов активизаций: она субмеридиональна и проходит примерно по $105^{\circ}$ в. д., отделяя центральную часть Байкальской рифтовой системы и ее северо-восточный фланг от юго-западного фланга. Закономерные согласованности в пространственной направленности активизации разломов в различных иерархических группах свидетельствуют о том, что генераторами описываемого процесса могут быть медленные деформационные волны разных длин, чувствительность к которым различна у выделенных групп разломов, характеризующихся разной длиной.

Источниками подобных волн, возможно, являются продолжающиеся процессы активного рифтогенеза, приводящие к эпизодическим подвижкам всей межблоковой границы между Сибирской и Амурской (Забайкальской) плитами, а также более локальные смещения между блоками других рангов на флангах и в центральной части Байкальской рифтовой системы - наиболее геодинамически активной территории рассматриваемого региона. Высокая вероятность возбуждения волн в связи с подвижками блоков, лежащих на вязком основании, согласуется с расчетами [Николаевский, Рамазанов, 1986; Невский, 1999; и др.]. Ранее к близким выводам о волновом процессе, пространственно определяющем возникновение очагов землетрясений, но с иным критерием структурного контроля, пришел В.И. Уломов [1993]. В настоящее время факт существования деформационных волн в зонах разломов не вызывает сомнений [Быков, 2005]. Их можно рассматривать как один из классов механических движений, свойственных земной коре и литосфере в целом [Гольдин, 2004].

\section{СЛАБАЯ СЕЙСМИЧЕСКАЯ АКТИВНОСТЬ ВОСТОЧНОЙ ЧАСТИ СИБИРСКОЙ ПЛАТФОРМЕННОЙ ПЛИТЫ}

Установлены основные особенности пространственного (рис. 11, $A$ ) и временного (рис. 11, Б) распределений сейсмических событий в пределах Иркутского амфитеатра: 1) полоса проявления платформенных землетрясений непосредственно примыкает к традиционно выделяемой северной границе Саяно-Байкальского сейсмического пояса и повторяет ее очертания; 2) существует общая тенденция уменьшения плотности землетрясений от краевого шва в глубь платфрормы, на фоне которой имеет место чередование продольных полос пониженной и повышенной концентрации эпицентров, причем эта зональность закономерно распространяется в центральную часть Саяно-Байкалького пояса; 3) различие в интенсивности сейсмического процесса, свойственное западной и восточной ветвям пояса, в полной мере проявляется на платформе в виде узкой присаянской полосы рассеянной сейсмичности и широкой прибайкало-патомской части, характеризующейся наличием серии отчетливо выраженных скоплений эпицентров и участков 


\section{Группа 1}

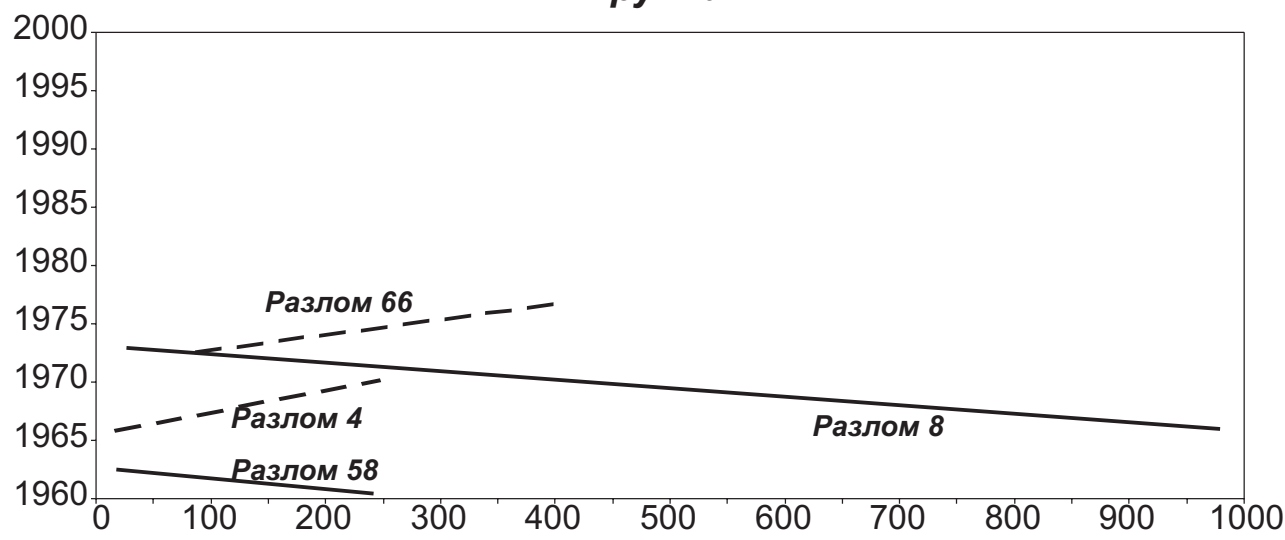

Группа 2
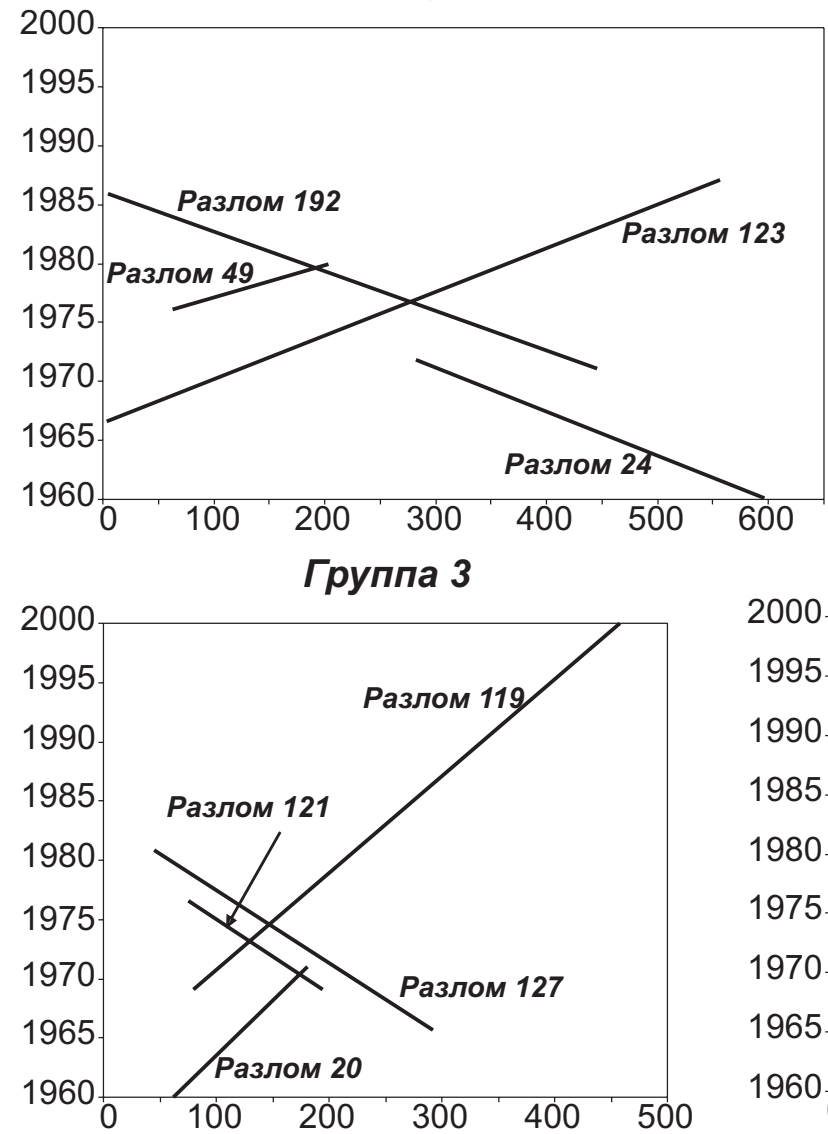

Группа 4

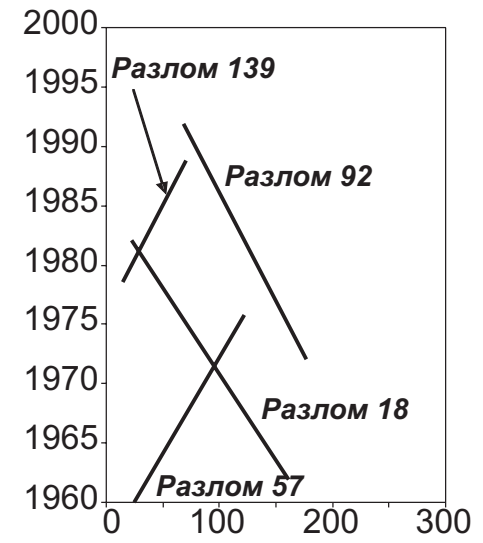

Рис. 8. Примеры графиков временных трендов сейсмических событий в четырех группах разломов с разными скоростными характеристиками активизации.

Оси ординат - годы сейсмических событий; оси абсцисс - длины разломов, км.

Fig. 8. Sample curves showing temporal trends of seismic events in four groups of faults differing by activation velocity rates. Fault length, km are given in X-axes. Years of seismic events are shown on $\mathrm{Y}$-axes show.

их практически полного отсутствия; 4) на платформенной территории и в Саяно-Байкальском поясе имеет место аналогичный в качественном отношении вид временных вариаций сейсмической активности, выражающийся в наличии ее всплесков (1969-1972, 1977-1981, 1987-1988, 1993-1995 гг.) на фоне сравнительно равномерного течения процесса; 5) всплески сейсмической активности на платформе происходят примерно в одно время с аналогичными процессами в подвижном поясе; 6) активизация сейсмического процесса на платформе опережает или запаздывает на 1-2 года по отношению к всплеску сейсмичности в поясе [Seminskii, Radziminovich, 2007].

Установленные закономерности свидетельствуют об устойчивом соответствии пространственновременного развития сейсмического процесса в краевой части платформы и окружающем ее под- 


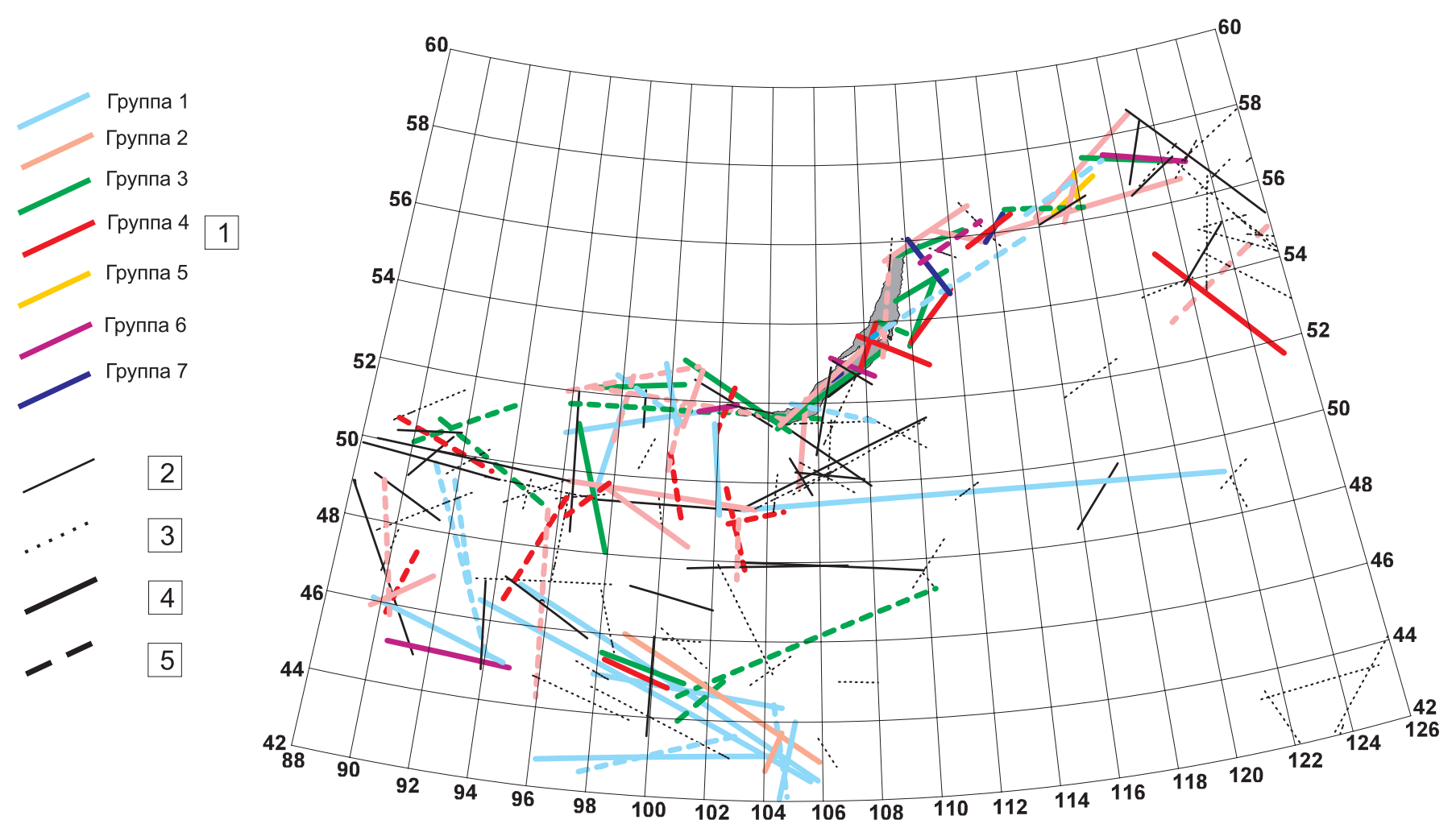

Рис. 9. Активные разломы Центральной Азии и их группирование по параметрам современной активизации. 1 - номера групп разломов; 2 - разломы с неопределенными параметрами активизации; 3 - неактивные разломы; 4, 5- разломы с преобладающими векторами движения волн возмущения: 4 - с востока на запад; 5 - с запада на восток.

Fig. 9. Active faults in the Central Asia and their groups with regard to parameters of recent activation. $1-$ numbers of fault groups according to the table given in the article; 2 - faults with undetermined parameters of activation; 3 - inactive faults; 4,5 - faults with dominating vectors of movements of disturbance waves: 4 - from east to west; 5 - from west to east.

вижном поясе. Следовательно, в данном случае контактирование литосферных блоков осуществляется в широкой зоне с закономерным внутренним строением, но характеризуется существенным уменьшением интенсивности деструктивного процесса на платформе в связи с ее повышенной жесткостью и удаленностью от источника напряжений. В то же время фиксация землетрясений на столь обширной платформенной территории в совокупности с увеличением нагрузки на горный массив в районах ангарских водохранилищ и интенсивным освоением отдельных регионов выдвигает проблему широкомасштабного изучения сейсмоактивных разломов на юге Сибирской платформы в разряд наиболее актуальных направлений прикладных тектонофизических исследований.

\section{ПРАКТИЧЕСКОЕ ПРИМЕНЕНИЕ КОМПЛЕКСА ТЕКТОНОФИЗИЧЕСКИХ МЕТОДОВ ПРИ ИЗУЧЕНИИ РАЗЛОМНОЙ ТЕКТОНИКИ, НАПРЯЖЕННОГО СОСТОЯНИЯ ЛИТОСФЕРЫ И ЕЁ СЕЙСМИЧНОСТИ}

Комплексные тектонофизические исследования разломов и сейсмичности района строительства Северо-Муйского тоннеля трассы БАМ позволили выявить основные закономерности блоковой тектоники, особенности распределения, кинематику и внутреннее строение зон разноранговых разломов. На основе детальной характеристики сейсмичности района выявлены закономерности связи гипоцентрального поля с современным разломообразованием в земной коре. Реконструированы поля палеонапряжений района на разные этапы геологической истории. Сделан вывод об изменении типа напряженного состояния земной коры в течение этапа неотектонического развития. Разработана тектодинамическая модель формирования разломно-блоковой структуры Северо-Муйского геодинамического полигона как дуплекса в зоне формирующегося межплитного разлома сдвиговой природы [Саньков u дp., 1991].

Полученные данные о нарушенности горного массива разломами (карты разломов), выводы о его напряженном состоянии на основе анализа трещиноватости и механизмов очагов землетрясений использовались производственными организациями при проходке выработок Северо-Муйского тоннеля, а также при его последующей многолетней эксплуатации и устранении последствий многочисленных природных катастрофических событий различной степени опасности [Быкова, Шерман, 2007].

Прикладные аспекты тектонофизических закономерностей внутреннего строения континентальных разломных зон, стратегия и тактика их исполь- 


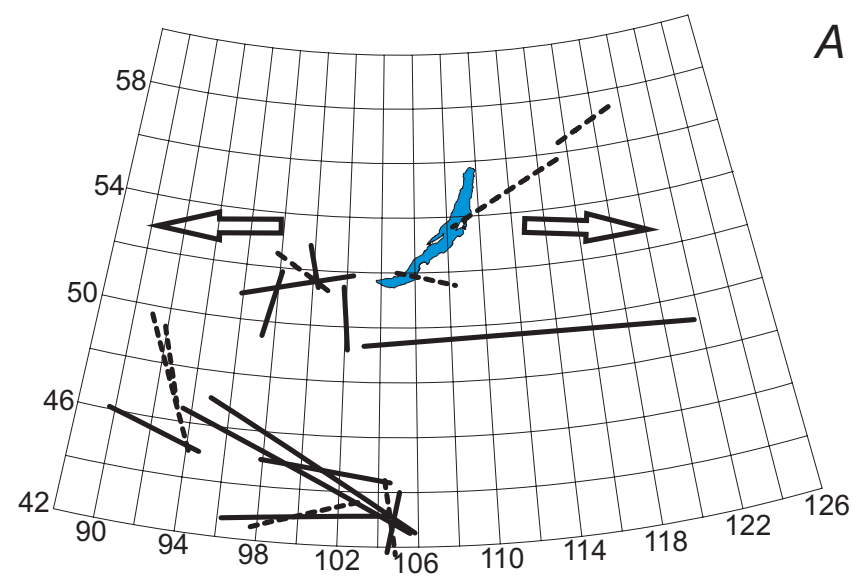

$A$
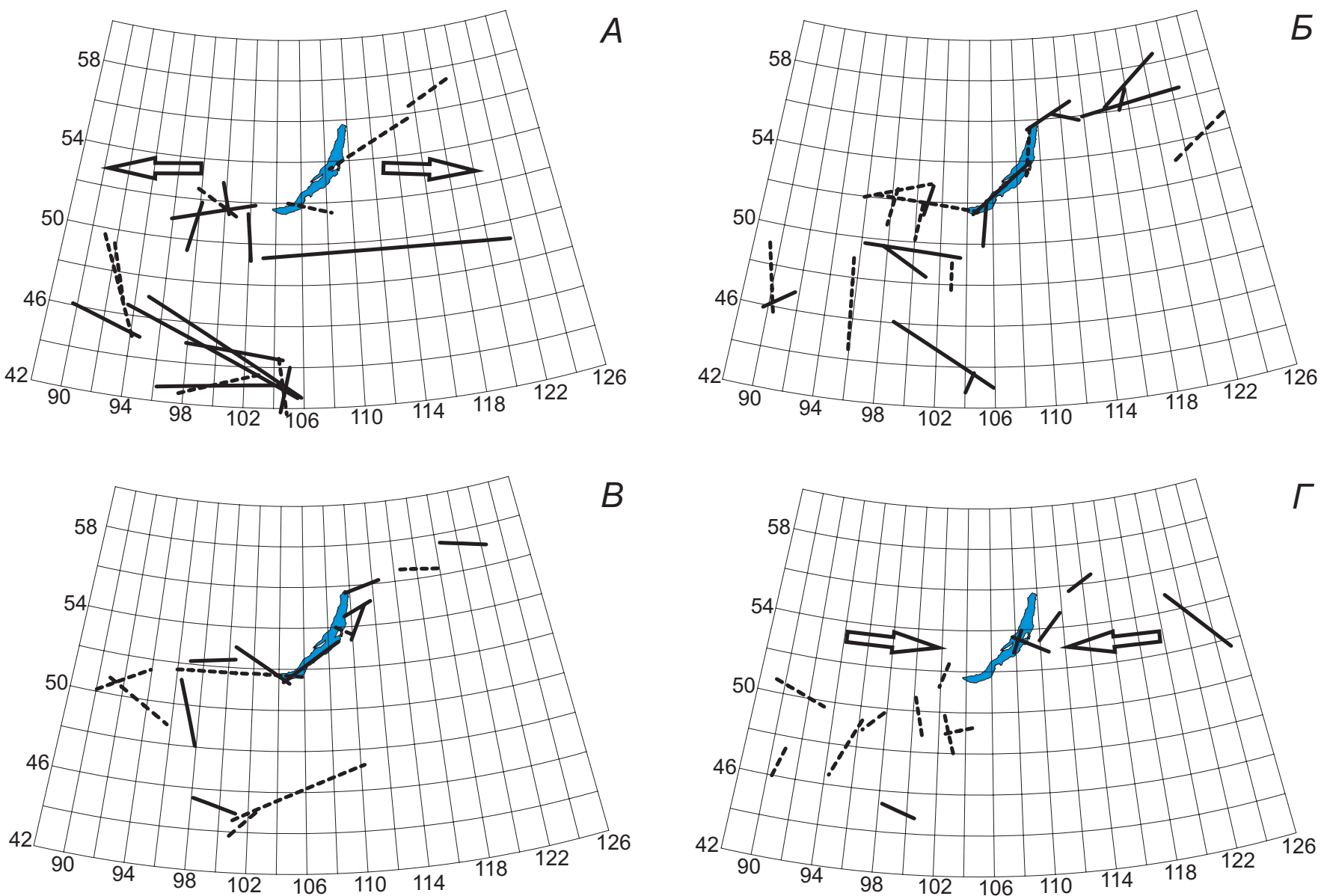

Рис. 10. Расположение активных разломов Центральной Азии с различными скоростями и векторами деформационных волн возбуждения. $A$ - разломы 1-й группы; $Б$ - разломы 2-й группы; $B$ - разломы 3-й группы; $Г$ - разломы 4-й группы.

Пунктирная линия - вектор активизации разломов направлен с запада на восток; сплошная линия - вектор активизации разломов направлен с востока на запад. Стрелки - примерное направление фронта деформационных волн возбуждения (активизации) разломов.

Fig. 10. Positions of active faults in the Central Asia that differ by velocities and vectors of deformational disturbance waves. $A-$ faults of group $1 ; \overline{-}$ - faults of group $2 ; B$ - faults of group $3 ; \Gamma$ - faults of group 4.

Vectors of fault activation from west to east are shown by dotted line, those from east to west by solid line. Arrows show approximate direction of the front of deformational waves of disturbance (activation) of faults.

зования для решения сейсмологических, металлогенических, инженерно-геологических и гидрогеологических задач детально рассмотрены в монографии К.Ж. Семинского, А.С. Гладкова, О.В. Луниной и М.А. Тугариной [2005]. В книге авторам удалось неформально объединить и представить на современном уровне существенно разные по масштабу и значимости аспекты сложной проблемы разломообразования в литосфере и контролируемые при этом разрывами существенно разные процессы и явления, сопутствующие деструкции.

Более узкую, но не менее значимую в прикладном плане работу выполнили А.С.Гладков, С.А. Борняков, А.В. Манаков, В.А. Матросов [2008]. Они обобщили опыт комплексных тектонофизических исследований в пределах Якутской алмазоносной провинции, направленных на выяснение структурных фракторов контроля пространственной локализации кимберлитовых тел. В основу исследований положены тектонофизические и геофизические методы, часть из которых носят оригинальный харак- тер и впервые адаптированы для платформенной территории, что придает работе методическую направленность. Оригинальный полевой структурногеологический материал, собранный авторами в пределах Далдыно-Алакитского и Мало-Ботуобинского кимберлитовых районов по единой методологии, лег в основу построения разномасштабных разломно-блоковых схем и общей для них геодинамической модели.

Изложенные в лапидарной форме далеко не полные результаты многолетних тектонофизических исследований сотрудников Института земной коры СО РАН дают основание наметить их перспективы.

\section{ПЕРСПЕКТИВЫ ДАЛЬНЕЙШИХ ТЕКТОНОФИЗИЧЕСКИХ ИССЛЕДОВАНИЙ ПРОЦЕССА ДЕСТРУКЦИИ ЛИТОСФЕРЫ}

При изучении собственно процессов разломообразования особое внимание необходимо уделить реологической изменчивости среды с глубиной, ее 

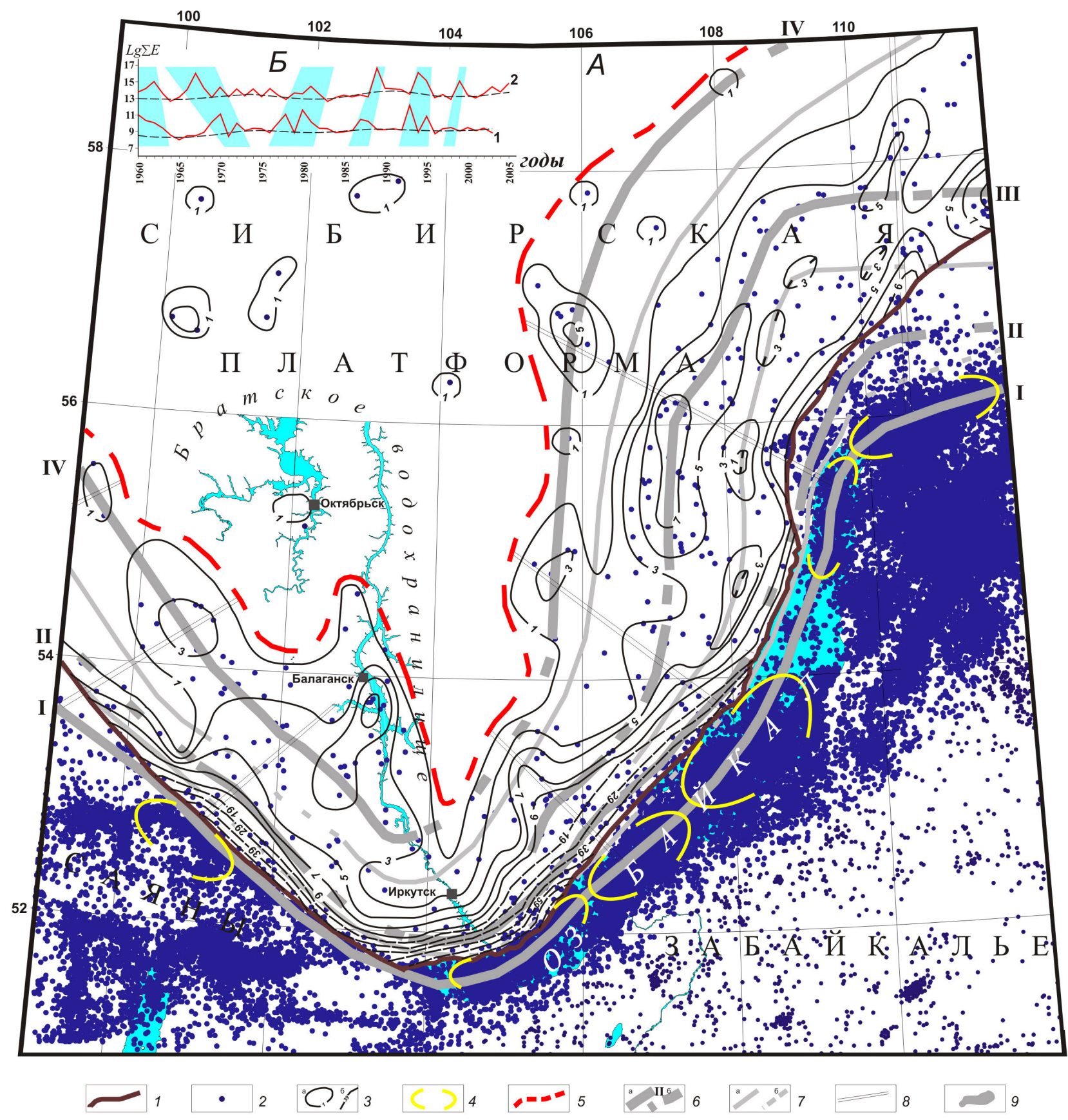

Рис. 11. Пространственно-временные особенности проявления землетрясений, произошедших в пределах БРС и смежных территорий с 1960 по 2005 г.

A. Распределение эпицентров землетрясений на юге Сибирской платформы. 1 - краевой шов Сибирской платформы; 2 - эпицентр землетрясения; 3 - изолинии плотности эпицентров, рассчитанные с использованием окна палетки размером $0,5 \times 0,5^{\circ}$ и проведенные с шагом 2 (а) и 10 (б); 4 - участки («пятна») высокой сейсмической активности в осевой части Саяно-Байкальского сейсмического пояса; 5 - граница поля рассеянной сейсмичности на Сибирской платформе; 6 - положение (а) (в т.ч. - предполагаемое (б)) и порядковый номер оси у продольной полосы повышенной плотности эпицентров землетрясений; 7 - положение (а) (в т.ч. - предполагаемое (б)) оси у продольной полосы пониженной плотности эпицентров землетрясений; 8 - линия, соединяющая сейсмические «пятна» осевой части Саяно-Байкальского сейсмического пояса с участками повышенной плотности эпицентров в платформенном поясе рассеянной сейсмичности; 9 - крупные водоемы.

Б. Графики изменения во времени логарифмма суммарной энергии ночных землетрясений (IgE), произошедших за год в поясе рассеянной сейсмичности платформы (1), и событий, имевших место южнее ее краевого шва в Саяно-Байкальском сейсмическом поясе (2) с ограничением на западе и востоке по меридианам 99 и 112 (полосами голубого цвета объединены примерно совпадающие по времени периоды активизации сейсмического процесса на платформе и в сейсмическом поясе).

Fig. 11. Specific features of time-and-space occurrence of earthquakes' occurrence within the Baikal rift system and its adjacent territories from 1960 to 2005

A. Earthquake epicentres in the southern Siberian platform. 1 - marginal suture of the Siberian platform; 2 - earthquake epicentre; 3 - epicentre density isolines calculated with $0.5 \times 0.5^{\circ}$ grid and level distances 2 (a) and 10 (б); 4 - sites ("spots") of high seismicity in the axial part of the Sayan-Baikal seismic belt; 5 - boundary of the dispersed seismicity field in the Siberian platform; 6 - defined (a) and arbitrarily defined (б) positions and numbers of axes at the longitudinal belt of higher density of earthquake epicentres; 7 - defined (a) and arbitrarily defined (б) positions of axes at the longitudinal belt of lower density of earthquake epicentres; 8 - line connecting seismic "spots" of the axial part of the Sayan-Baikal seismic belt with sites of higher density of earthquake epicentres in the platform dispersed seismicity belt; 9 - large water bodies. 
Б. Curves showing temporal changes of logarithm of summary energy of night earthquakes $(I g E)$ which occurred within one year in the platform dispersed seismicity belt (1), and temporal changes of events which occurred southward from the platform's marginal suture in the Sayan-Baikal seismic belt (2), with limits in east and west by meridians 99 and 112 . Blue lines connect seismicity activation periods for the platform and the seismic belt that are roughly coincident in time.

влиянию на внутреннюю структуру разломов и изменению их свойств (псевдовязкости и др.) как пограничных структур. Важно уточнить соотношения параметров для крупных (трансрегиональных) разломов литосферы. Длины таких разломов, размеры областей их динамического влияния, многократно повторяемые подвижки и накопленные амплитуды смещений связаны между собою сложными нелинейными зависимостями. При их оценке фактор геологического времени является одним из определяющих параметров. Фактическим материалом при этих работах должны явиться результаты детальных полевых исследований на нескольких тектонотипах разрывов в сочетании с физическим моделированием на многослойных моделях с использованием материалов различной вязкости.

В центре внимания должны находиться проблемы дальнейшего развития представлений о зонах современной деструкции литосферы. Здесь необходимо, во-первых, продолжить выявление аналогичных структур на разных иерархических уровнях их организации в регионах с отличающимися геодинамическими режимами и, во-вторых, исследовать особенности их внутреннего строения на основе сопоставления с установленными закономерностями фрормирования крупных разломов литосферы. Особый акцент должен быть сделан на изучении характера взаимодействия зон современной деструкции литосферы и граничащих с ними блоков, что в значительной степени предопределяет пути активизации разрывной структуры и, как следствие этого, закономерности проявления сейсмичности.

Следующий этап разработки проблемы динамики разломных зон видится в скрупулезном качественном и количественном изучении влияния отдельных природных факторов на проявление главных закономерностей разломообразования, т.е. в приложении теоретических результатов к конкретным природным ситуациям. При этом знание наиболее общих особенностей динамики структурообразования в разломных зонах (стадийность развития, зональность внутреннего строения, пространственно-временная неравномерность развития и др.) должно быть отправной точкой исследований подобного типа. В конечном итоге выявленные теоретические закономерности разломообразования в литосфере станут реальным инструментом решения прикладных вопросов формирования структуры природных регионов.

Нельзя считать полностью исчерпанными методические проблемы тектонофизики. Перспективы полевого изучения разломно-блоковой структуры земной коры связаны с дальнейшей разработкой способов ее картирования на основе выявления трещинных парагенезисов с целью создания единой, полностью формализованной методики. Это позволит разработать ее компьютерную версию для широкого внедрения в практику геолого-разведочных работ.

Закономерности деформации литосферы во времени и пространстве тесно связаны с другими синхронно протекающими процессами, в частности с сейсмичностью [Ружич, 1997]. В ближайшей перспективе ставится задача комплексными тектонофизическими методами определять критерии современной активизации разломов или их фрагментов, следствием которой является сейсмичность. При этом комплекс тектонофизических методик, используемый для оценки тектонической активности и сейсмической опасности территорий интенсивного природопользования, планируется усилить, с одной стороны, за счет вовлечения в анализ количественной информации о движениях земной коры, а с другой - проведением физического моделирования конкретных природных обстановок. Это позволит в конечном итоге поставить цикл тектонофризических исследований на один уровень значимости с применяемыми в настоящее время способами оценки сейсмоопасности территорий по сведениям об уже прошедших сейсмических событиях [Шерман и др., 2000б].

В последние годы расширилось представление о роли разломов литосферы в формировании природных и природно-техногенных чрезвычайных ситуаций [Лобацкая, Коффф, 1997; и мн. др.]. Разломы и области их динамического влияния являются фактором, часто вызывающим нарушение геоэкологического баланса и возникновение чрезвычайных ситуаций. С этой точки зрения очень важны мониторинговые наблюдения за активными разломными зонами, в области динамического влияния которых находятся социально важные объекты. Назрела необходимость разработать специальные дополнительные требования к строительным нормам и правилам, а также пересмотреть некоторые критерии сейсмических шкал с целью внесения в них дополнений о требованиях к строительству в областях влияния активных разломов. Важное значение приобретает проблема разработки региональных шкал сейсмической интенсивности, первый опыт создания которых тесно связан с Восточно-Сибирской научной тектонофизической школой [Шерман и др., 2003].

\section{ЗАКЛЮЧЕНИЕ}

Тектонофизическое изучение разломов и разломно-блоковых структур литосферы, начатое М.В. Гзовским, развиваемое в Восточно-Сибирской тектонофизической школе Института земной коры СО РАН, позволило сделать качественный скачок в знаниях о закономерностях развития этих структур: 
от пространственных и временных геологических факторов развития к квантификации параметров и физическим закономерностям деструкции литосферы. Это является обоснованием перехода в изучении разломной тектоники от геологического картирования разломов и блоков, через проведение тектонофизического анализа, к пониманию основополагающих законов процесса деструкции литосферы.

Исследования поддержаны программой 16.8 Президиума РАН, Федеральной целевой программой в рамках госконтракта 02.740.11.0446, программами ОНЗ РАН 6 и 7, интеграционным проектом СО РАН № 61, грантами РФФИ 07-05-00251, 09-0512023-офи_м; 07-05-00061 и 08-05-98062.

\section{ЛИТЕРАТУРА}

Адамович А.Н. Анализ перехода систем фрагментов деструкции в магистральный шов // Изв. РАН. Физика Земли. - 1997. № 8. - С. 65-69.

Борняков С.A. Количественный анализ параметров разномасштабных сдвигов (по результатам моделирования) // Геология и геофизика. - 1990. - № 9. - С. 34-42.

Борняков С.А., Гладков А.С., Матросов В.А., Адамович А.Н., Клепиков B.A. Нелинейная динамика разломообразования по результатам физического моделирования // Геотектоника. 2004. - № 5. - C. 85-95.

Борняков С.А., Шерман С.И., Гладков А.С. Многоуровневая самоорганизация деструктивного процесса в сдвиговой зоне // Физическая мезомеханика. - 2000. - Т. 3, № 4. - С. 107-115.

Быков В.Г. Деформационные волны Земли: концепция, наблюдения и модели // Геология и геофизика. - 2005. - Т. 46, № 11. - С. $1176-1190$.

Быкова Н.М., Шерман С.И. Северо-Муйский тоннель - из XX в XXI век. - Новосибирск: Наука, 2007. - 186 с.

Гзовский М.В. Основы тектонофизики. - М.: Наука, 1975. - 536 с.

Гладков А.С., Борняков С.А., Манаков А.В., Матросов В.А. Тектонофизические исследования при алмазопоисковых работах. Методическое пособие. - М.: Научный мир, 2008. - 175 с.

Гольдин С.В. Деструкция литосферы и физическая мезомеханика // Физическая мезомеханика. - 2002. - Т. 5, № 5. С. 5-22.

Гольдин C.В. Дилатансия, переупаковка и землетрясения // Физика Земли. - 2004. - № 10. - С. 37-54

Леви К.Г. Неотектонические движения в сейсмоактивных зонах литосферы. Тектонофизический анализ. - Новосибирск: Наука, 1991. - 166 с.

Лобацкая Р.М. Структурная зональность разломов. - М.: Недра, 1987. - $128 \mathrm{c}$

Лобацкая Р.М., Коффф Г.Л. Разломы литосферы и чрезвычайные ситуации. - М.: Институт литосферы РАН, 1997. - 196 с.

Логачев Н.А., Борняков С.А., Шерман С.И. О механизме формирования Байкальской рифтовой зоны по результатам физического моделирования // Доклады АН. - 2000. - Т. 373, № 3. - С. 388-390.

Лучищкий И.В., Бондаренко П.М. Эксперименты по моделированию сводовых поднятий Байкальского рифта // Геотектоника. - 1967. - № 2. - С. 3-20.

Невский М.В. Геофизика на рубеже веков // Избранные труды ученых ОИФЗ РАН. - М.: ОИФЗ РАН, 1999. - С. 124-139.

Николаевский В.Н., Рамазанов Т.К. Генерация и распространение волн вдоль глубинных разломов // Известия АН СССР. Физика Земли. - 1986. - № 10. - С. 3-13.

Парфреевец А.В., Саньков В.А. Напряженное состояние земной коры и геодинамика юго-западной части Байкальской рифтовой системы. - Новосибирск: Академическое изд-во «Гео», 2006. $-151 \mathrm{c}$

Ружич В.В. Сейсмотектоническая деструкция в земной коре Байкальской рифтовой зоны. - Новосибирск: Изд-во СО РАН, 1997. - 147 c

Садовский М.А., Болховитинов Л.Г., Писаренко В.Ф. Деформирование геофизической среды и сейсмический процесс. - М.: Наука, 1987. - 102 с.

Саньков В.А. Глубины проникновения разломов. - Новосибирск: Наука, 1989. - 105 с
Саньков В.А., Днепровский Ю.И., Коваленко С.Н., Борняков С.А., Гилева Н.А., Горбунова Н.Г. Разломы и сейсмичность Северо-Муйского геодинамического полигона. - Новосибирск: Наука, 1991. - 111 с.

Саньков В.А., Мирошниченко А.И., Парфреевец А.В., Аржанникова А.В., Лухнев А.B. Позднекайнозойское напряженное состояние земной коры Прихубсугулья (Северная Монголия) по натурным и экспериментальным данным // Геотектоника. 2004. - № 2. - С. 78-90.

Семинский К.Ж. Структурно-механические свойства глинистых паст как модельного материала в тектонических экспериментах. - Иркутск: ВИНИТИ, 1986а. - №5762-В86. - 130 с.

Семинский К.Ж. Анализ распределения опережающих разрывов при формировании крупных дизъюнктивов // Геология и геофизика. - 1986б. - № 10. - С. 9-18.

Семинский К.Ж. Общие закономерности динамики структурообразования в крупных сдвиговых зонах // Геология и геофизика. - 1990. - № 4. - С. 14-23.

Семинский К.Ж. Принципы и этапы спецкартирования разломноблоковой структуры на основе изучения трещиноватости // Геология и геофизика. - 1994. - № 9. - С. 112-130.

Семинский К.Ж. Тектонофизические закономерности деструкции литосферы на примере Гималайской зоны сжатия // Тихоокеанская геология. - 2001. - Т. 20, № 6. - С. 17-30.

Семинский К.Ж. Внутренняя структура континентальных разломных зон. Тектонофизический аспект. - Новосибирск: Изд-во СО РАН, фоллиал «Гео». - 2003. - 244 с.

Семинский К.Ж. Картирование разломно-блоковой структуры земной коры на современном этапе развития тектонофизики // Геофизический журнал. - 2005. - Т. 27, № 1. - С. 85-96.

Семинский К.Ж., Гладков А.С., Лунина О.В., Тугарина М.А. Внутренняя структура континентальных разломных зон. Прикладной аспект. - Новосибирск: Изд-во СО РАН, Филиал «Гео», 2005. -294 c.

Уломов В.И. Волны сейсмогеодинамической активизации и долгосрочный прогноз землетрясений // Физика Земли. - 1993. № 4. - C. 43-53.

Шерман С.И. Физические закономерности развития разломов земной коры. - Новосибирск: Наука, 1977. - 102 с.

Шерман С.И. Физический эксперимент в тектонике и теория подобия // Геология и геофизика. - 1984. - № 3. - С. 8-18.

Шерман С.И. Деструктивные зоны литосферы, их напряженное состояние и сейсмичность // Неотектоника и современная геодинамика континентов и океанов. - М.: ГЕОС, 1996. С.76-79.

Шерман С.И. Развитие представлений М.В. Гзовского в современных тектонофизических исследованиях разломообразования и сейсмичности в литосфере // Тектонофизика сегодня. - М.: ОИФЗ РАН, 2002. - С. 49-59.

Шерман С.И., Бабичев А.А. Теория подобия и размерностей в приложении к тектоническому моделированию // Экспериментальная тектоника. Методы, результаты, перспектива. М.: Наука, 1989. - С. 57-77.

Шерман С.И., Бержинский Ю.А., Павленов В.А., Аптикаев Ф.Ф. Региональные шкалы сейсмической интенсивности. - Новосибирск: Изд-во СО РАН, филиал «Гео», 2003. - 189 с.

Шерман С.И., Борняков С.А., Буддо В.Ю. Области динамического влияния разломов. - Новосибирск: Наука, 1983. - 112 с.

Шерман С.И., Демьянович В.М., Лысак С.В. Сейсмический процесс и современная многоуровневая деструкция литосферы в Байкальской рифтовой зоне // Геология и геофизика. 2004. - T. 45, № 12. - С. 1458-1470.

Шерман С.И., Днепровский Ю.И. Поля напряжений земной коры и геолого-структурные методы их изучения. - Новосибирск: Наука, 1989. - 157 с.

Шерман С.И., Лунина О.В. Новая карта напряженного состояния верхней части литосферы Земли // Доклады АН. - 2001. - Т. 378, № 5. - С. 672-674.

Шерман С.И., Нгуен Тронг Ием, Семинский К.Ж.Новая карта разломно-блоковой тектоники территории Вьетнама // Доклады АН. - 2000а. - Т. 371, № 5. - С. 671-674.

Шерман С.И., Савитский В.А. Новые данные о квазипериодических закономерностях активизации разломов в реальном времени на основе мониторинга магнитуд сейсмических событий (на примере Байкальской рифтовой системы) // Доклады $\mathrm{AH}-2006$. - Т. 408, № 3. - С. 398-403.

Шерман С.И., Семинский К.Ж., Борняков С.А., Буддо В.Ю., Лобацкая Р.М., Адамович А.Н., Трусков В.А., Бабичев А.А. Разломообразование в литосфере. Зоны сдвига. - Новосибирск: 
Наука, 1991. - 261 с.

Шерман С.И., Семинский К.Ж., Борняков С.А., Адамович А.Н., Лобацкая Р.М., Лысак С.В., Леви К.Г. Разломообразование в литосфрере. Зоны растяжения. - Новосибирск: Наука, 1992. $262 \mathrm{c}$.

Шерман С.И., Семинский К.Ж., Борняков С.А., Адамович А.Н., Буддо В.Ю. Разломообразование в литосфере. Зоны сжатия. - Новосибирск: Наука, 1994. - 263 с.

Шерман С.И., Семинский К.Ж., Борняков С.А., Адамович А.Н., Гладков А.С. Теоретические и практические следствия развития идей М.В. Гзовского в исследованиях Института земной коры СО РАН // М.В. Гзовский и развитие тектонофизики / Отв. ред. Ю.Г. Леонов, В.Н. Страхов. - М.: Наука, 2000б. C. $245-265$

Шерман С.И., Семинский К.Ж., Черемных А.В. Деструктивные зоны и разломно-блоковые структуры Центральной Азии // Тихоокеанская геология. - 1999. - Т. 18, № 2. - С. 41-53.

Шерман С.И., Сорокин А.П., Савитский В.А. Новые методы классификации сейсмоактивных разломов литосфреры по индексу сейсмичности // Доклады АН. - 2005. - Т. 401, № 3. - С. 395-398.

Levi K.G., Sherman S.I. Applied geodynamic analysis // Musee Royal De L'Afrique centrale. V. 100. - Tervuren, Belgique Annales,Sciences Geologiques, 1995. - 133 p.

San'kov V.A., Miroshnitchenko A.I., Levi K.G., Lukhnev A.V., Melnikov A.I., Delvaux D. Cenozoic stress field evolution in the Baikal rift zone // Bull. Centre Rech. Elf Explor. Prod. - 1997. V. 21,
№ 2. -P. 435-455.

Scholz C.H. The mechanics of earthquakes and faulting. - New York: Cambridge University Press, 2002. - $283 \mathrm{p}$.

Seminskii K.Zh., Kogut E.I. Governing factors in the development of depressions and faults in the Baikal rift zone: results of a physical experiment // Doklady Earth Sciences. - 2009. - V. 424, № 1. P. $15-18$.

Seminskii K.Zh., Radziminovich Ya.B. Seismicity of the Southern Siberian Platform: spatiotemporal characteristics and genesis /I Izvestiya, Physics of the Solid Earth. - 2007. - V. 43, № 9. - P. 726-737.

Sherman S.I. Faults of the Baikal rift zone // Tectonophysics. - 1978. - V. 45, № 1. - P. 31-39.

Sherman S.I. Faults and tectonic stresses of the Baikal rift zone // Tectonophysics. - 1992. - V. 208, № 1-3. - P. 297-307.

Sherman S.I., Dem'yanovich V.M., Lysak S.V. Active faults, seismicity and fracturing in the lithosphere of the Baikal rift system // Tectonophysics. - 2004. - V. 380, № 3-4. - P. 261-272.

Sherman S.I., Gladkov A.S. Fractals in studies of faulting and seismicity in the Baikal rift zone // Tectonophysics. - 1999. - V. 308. - P. 133-142.

Sherman S.I., Gorbunova E.A. Variation and origin of fault activity of the Baikal rift system and adjacent territories in real time // Earth science frontiers. - 2008. - V. 15, № 3. - P. 337-347.

Sherman S.I., Seminskiy K.Zh., Cheremnykh A.V. Destructive zones and fault-produced block structures of Central Asia // Geology of Pacific ocean. - 2000. - V. 16. - P. 231-252.

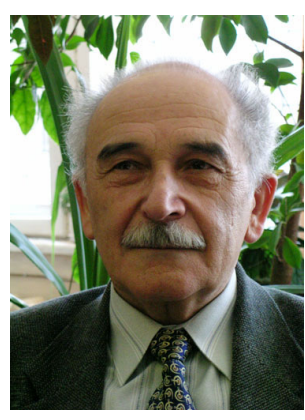

Шерман Семен Иойнович, академик Российской академии естественных наук, докт. геол.-мин. наук, профессор, г.н.с. ИЗК СО РАН

Научные работы связаны с тектонофизикой разломообразования в литосфере и синхронно протекающими процессами. Автор и соавтор более 300 опубликованных работ.

Институт земной коры СО РАН, 664033, Иркутск, ул. Лермонтова, 128 тел.: (3952) 428261 , e-mail: ssherman@crust.irk.ru

Sherman, Semen I., Academician of the Russian Academy of Natural Sciences, Doctor of Geology and Mineralogy, Professor, Chief Researcher

Field of research: Tectonophysics of faulting in the lithosphere, and processes synchronous to faulting. Author and co-author of more than 300 publications.

Institute of the Earth's Crust, Siberian Branch of RAS

128 Lermontov street, Institute of the Earth's Crust, Irkutsk 664033, Russia

Tel.: (3952) 428261. e-mail: ssherman@crust.irk.ru

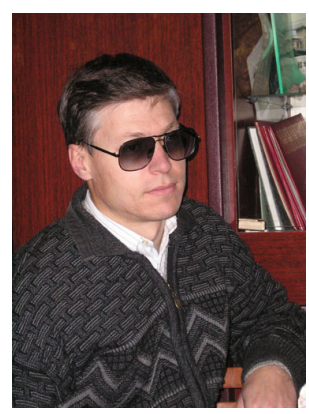

Семинский Константин Жанович, докт. геол.-мин. наук, зав. лабораторией Институт земной коры СО РАН, 664033, Иркутск, ул. Лермонтова, 128 тел.: (3952) 423027 , e-mail: seminsky@crust.irk.ru

Seminsky, Konstantin Zh., Doctor of Geology and Mineralogy, Head of Laboratory Institute of the Earth's Crust, Siberian Branch of RAS.

128 Lermontov street, Institute of the Earth's Crust, Irkutsk 664033, Russia

Tel.: (3952) 423027. e-mail: seminsky@crust.irk.ru 